\title{
Post-Variscan evolution of the Anti-Atlas belt of Morocco constrained from low-temperature geochronology
}

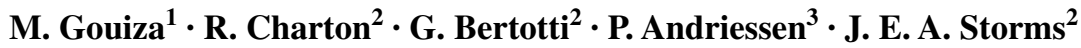

Received: 17 December 2015 / Accepted: 31 March 2016 / Published online: 20 April 2016

(C) The Author(s) 2016. This article is published with open access at Springerlink.com

\begin{abstract}
The Anti-Atlas belt of Morocco extends ENEWSW, over more than $600 \mathrm{~km}$, from the Atlantic margin in the west to the interior of the African plate in the east. It exhibits Precambrian rocks outcropping as basement inliers and surrounded by marine Ediacaran-Cambrian sequences around the axis of the mountain range. The belt, which has for a long time been interpreted as of Variscan age, is now revealed to have experienced major vertical movements through Mesozoic and Cenozoic times. Thereby, the Anti-Atlas domain appears to be affected by two episodes of exhumation separated by an episode of subsidence. The initial episode occurred in the Late Triassic and led to the exhumation of $7.5-10.5 \mathrm{~km}$ of crustal rocks by the end of the Middle Jurassic (ca. 160-150 Ma). The following phase resulted in 1-3 km of basement subsidence and occurred during the Late Jurassic and most of the Early Cretaceous. The basement rocks were then slowly brought to the surface after experiencing 2-3.5 km of exhumation throughout the Late Cretaceous and the Cenozoic. The timing of these episodes of exhumation and subsidence coincides with major tectonic and thermal events in relation with the evolution of the Atlantic and Tethys Oceans, indicating that the effects of their rifting and drifting extended beyond their presumed margins.
\end{abstract}

M. Gouiza

m.gouiza@leeds.ac.uk

1 School of Earth and Environment, University of Leeds, Leeds LS2 9JT, England, UK

2 Department of Geoscience and Civil Engineering, Delft University of Technology, Stevinweg 1, 2628 CN Delft, The Netherlands

3 Faculty of Earth and Life Sciences, VU University Amsterdam, De Boelelaan 1085, 1081 HV Amsterdam, The Netherlands
Keywords Morocco $\cdot$ Anti-Atlas belt $\cdot$ Vertical movements $\cdot$ Radiometric dating $\cdot$ Tectonics $\cdot$ Atlantic margin

\section{Introduction}

In Morocco, domains of outcropping Precambrian-Paleozoic basement along the Atlantic rifted margin (e.g., Meseta, Jebilet, Massif Ancient of Marrakech, and Anti-Atlas belt) were always recognized as relatively stable and not experiencing any major post-Variscan vertical movements (Michard 1976; Guiraud et al. 1987, 2005). However, recent findings, based on low-temperature geochronology techniques, show that the latter domains experienced $\mathrm{km}$-scale vertical motion (subsidence/exhumation) contemporaneous with the Mesozoic syn- and post-rift phases in the Central Atlantic (e.g., Malusà et al. 2007; Ghorbal et al. 2008; Ghorbal 2009; Sebti et al. 2009; Sebti 2011; Ruiz et al. 2011; Oukassou et al. 2013). Furthermore, well and seismic data reveal the existence of thick intervals of terrigenous siliciclastic sediments deposited in the adjacent Atlantic shelf and deep basins during Late Jurassic to Early Cretaceous time (e.g., Price 1981; Davison 2005; Gouiza 2011), which corresponds to the time interval of the aforementioned exhumation.

$\mathrm{Km}$-scale crustal movements during the early post-rift time are also documented elsewhere along the Atlantic Ocean: in the conjugate margin of Nova Scotia (Ravenhurst et al. 1990; Grist and Zentilli 2003; Pe-Piper and MacKay 2006; Li et al. 2012); the NE Brazilian margin (Harman et al. 1998; Peulvast et al. 2008; Bonow et al. 2009; Jelinek et al. 2014); and the W Greenland margin (Chalmers et al. 1999; Japsen et al. 2006; Bonow et al. 2006). Onshore domains along these margins experienced anomalous exhumation and denudation during the early Atlantic post-rift 
period when deposition of thick terrigenous series was taking place in neighboring offshore basins.

This work investigates the post-Variscan thermal history of the Anti-Atlas belt of Morocco, and its relation to the rifted Atlantic margin. Precambrian rocks, cropping out at the surface along the Anti-Atlas, were sampled to constrain their thermal evolution using apatite fission track (AFT) and (U-Th)/He thermochronology. The new measurements are integrated with existing data sets to quantify the magnitude of subsidence and exhumation along the entire belt and their lateral extent to the east, away from the presentday shoreline of the Atlantic Ocean.

\section{Geological setting of the Anti-Atlas belt}

The Anti-Atlas belt of Morocco extends ENE-WSW, over more than $600 \mathrm{~km}$, from the Atlantic margin in the west to the interior of the African plate in the east. It is located on the northern border of the West African craton (Fig. 1), which is bounded to the north by the High Atlas fold-andthrust belt. The Anti-Atlas and High Atlas are separated by the Neogene foreland basins of Souss and Ouarzazate (Figs. 2, 3), which are found on the foot-wall of a major structure that is the South Atlas Fault (known also as the South Atlas Front) (Dewey and Kidd 1974; Ennih and Liégeois 2001, 2008). The Anti-Atlas exhibits Precambrian rocks cropping out as basement inliers, surrounded by marine Ediacaran-Cambrian sequences along the axis of the mountain range (Figs. 2, 3). The latter sediments are overlain by Ordovician to Early Carboniferous sequences which extend south as cover of the West African craton (Soulaimani et al. 2014).

The tectonic and structural evolution of the Anti-Atlas is believed to be shaped by three major orogenic events; the Eburnean orogeny, the Neoproterozoic Pan-African

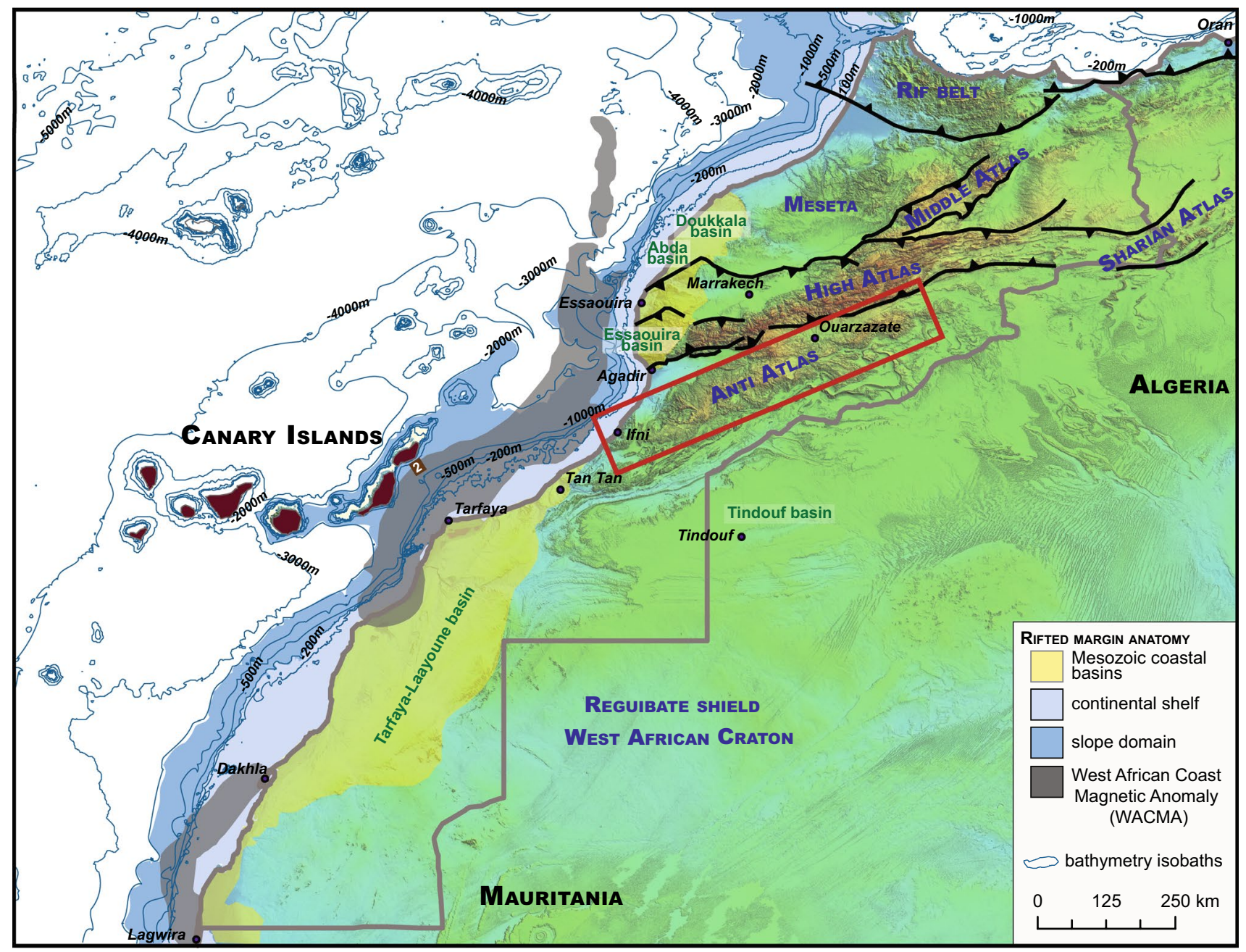

Fig. 1 Shaded relief map of Morocco showing the major structural domains, namely from north to south, the Rift Belt, the Meseta, the Middle and High Atlas ranges, the Anti-Atlas Belt, the West African Craton, and the Atlantic margin to the west 


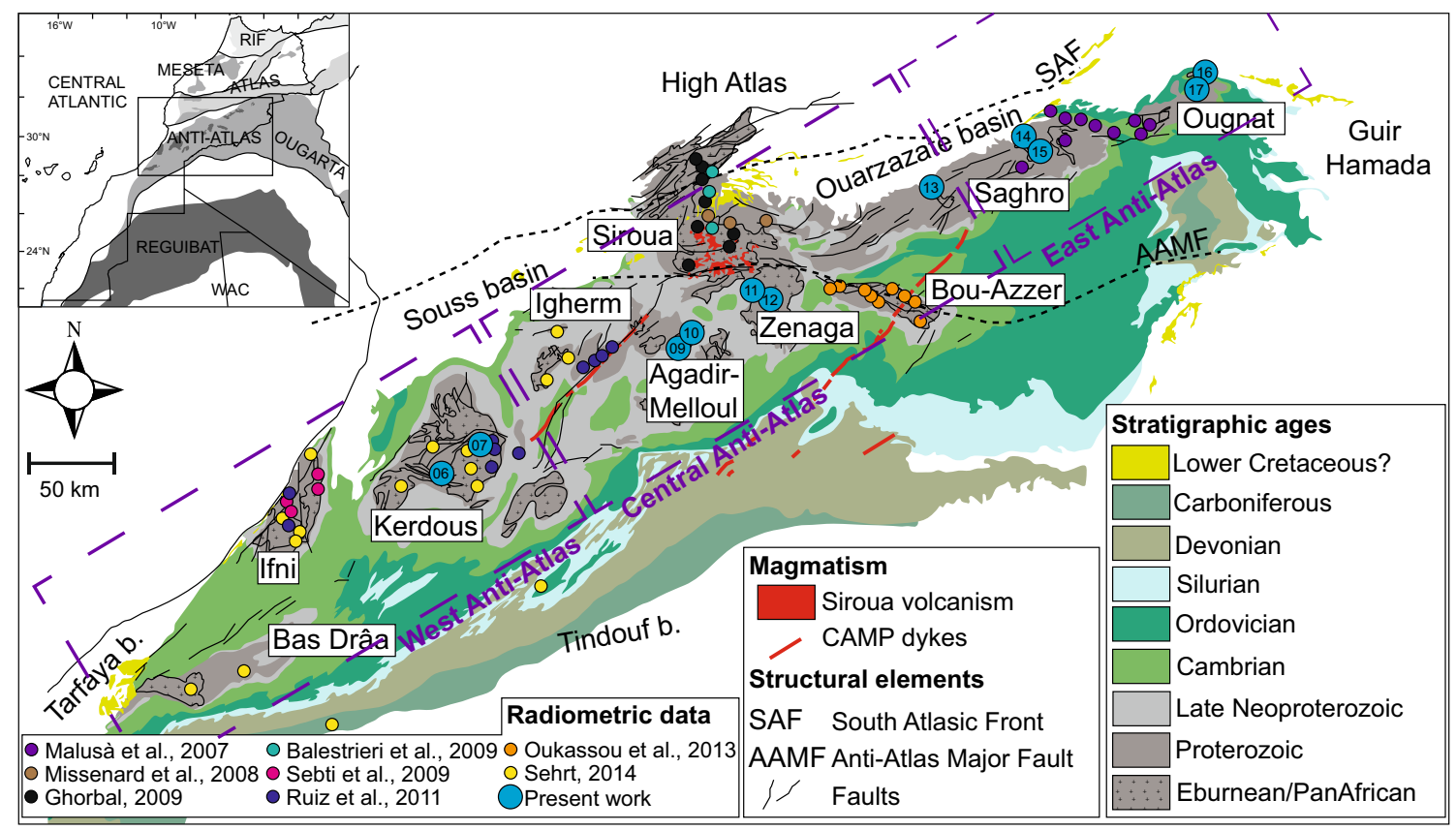

Fig. 2 Geological map of the Anti-Atlas Belt showing the Precambrian inliers, the major structures, and the location of the samples analyzed by low-T thermochronology in this work and previous studies. Map simplified from the geological map of Morocco $(1: 1,000,000)$

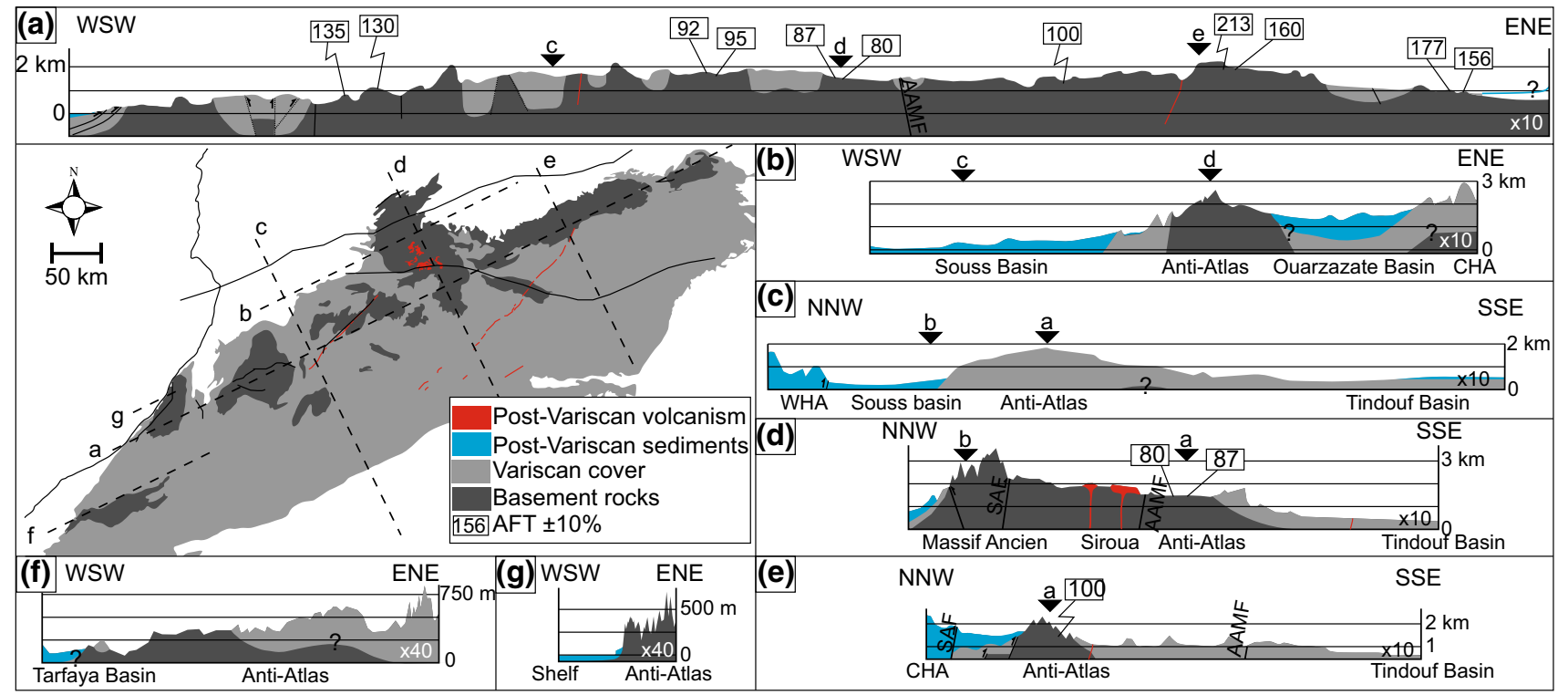

Fig. 3 Simplified geological cross section along and across the Anti-Atlas belt showing the major tectonic and lithological units. The crosssections were derived from the geological map of Morocco $(1: 1,000,000)$

orogeny and the Paleozoic Variscan orogeny. The AntiAtlas Major Fault (AAMF), which is inherited from the Pan-African shortening, runs roughly E-W and subdivides the belt into two distinct domains (Choubert 1947). South of the AAMF, the Anti-Atlas basement rocks consist of the Eburnean Paleoproterozoic schists and granitic intrusions and their Neoproterozoic shallow-water series, which were folded and metamorphosed during the Eburnean and the Pan-African orogenies (Walsh et al. 2002; Thomas et al. 2002; Gasquet et al. 2008; Soulaimani et al. 2014). North of the AAMF, the Anti-Atlas basement rocks are mainly Neoproterozoic of age. They consist of ophiolites and island arc-related gneiss and intrusions accreted to the northern edge of the West African craton during the climax 
Table 1 List of the samples analyzed in this work

\begin{tabular}{lllllll}
\hline Inlier & Sample name & Lithology & Age & Latitude & Longitude & Elevation \\
\hline Kerdous & MOR210-06 & Granites & Precambrian & 29.58162 & -9.17497 & 1090 \\
& MOR210-07 & Granites & Precambrian & 29.70680 & -8.96750 & 1045 \\
Agadir-Melloul & MOR210-09 & Granites & Precambrian & 30.19866 & -7.80825 & 1822 \\
& MOR210-10 & Granites & Precambrian & 30.28485 & -7.79115 & 1780 \\
\multirow{3}{*}{ Saghro } & MOR210-11 & Granites & Precambrian & 30.47779 & -7.37185 & 1568 \\
& MOR210-12 & Granites & Precambrian & 30.45819 & -7.35064 & 1550 \\
& MOR210-13 & Granites & Precambrian & 31.01398 & -6.43273 & 1284 \\
& MOR210-14 & Granites & Precambrian & 31.22250 & -5.76013 & 1831 \\
& MOR210-16 & Granites & Precambrian & 31.19869 & -5.75257 & 1987 \\
& MOR210-17 & Granites & Precambrian & 31.52191 & -4.77644 & 974 \\
\hline
\end{tabular}

of the Pan-African orogeny (ca. 850-540 Ma) (Kröner and Stern 2004; D'Lemos et al. 2006; Linnemann et al. 2008; Timmerman 2008; El Hadi et al. 2010; Hefferan et al. 2014; Soulaimani et al. 2014). During the Ediacaran, at the end of the Pan-African orogeny, the Anti-Atlas experienced post-orogenic collapse resulting in tilted basement blocks and continental basins filled by the Upper Ediacaran volcaniclastic series of the Ouarzazate Group (Gasquet et al. 2008; Soulaimani et al. 2014). During the Late Neoproterozoic-Early Cambrian, the Anti-Atlas domain experienced extension and rifting related to the opening of the Iapetus Ocean with the formation of wide graben and half-graben structures filled by coarse clastics and intervals of alkaline basalts (Taroudant and Tata Groups respectively) indicating an intracontinental extension (Benssaou and Hamoumi 2003; Burkhard et al. 2006; Soulaimani et al. 2014). The ensuing post-rift stage that started in the Cambrian led to strong subsidence in the Anti-Atlas and accumulation of fine-grained clastic sediments, which thickness reached up to $10 \mathrm{~km}$ in the west and $4 \mathrm{~km}$ in the east (Helg et al. 2004; Burkhard et al. 2006; Baidder et al. 2008).

In the Carboniferous-Early Permian, the Variscan belt which extended from the Meseta plateau in the north to the Mauritanides in the south resulted in thick-skinned inversion and folding of the Anti-Atlas basement (Piqué et al. 1987; Helg et al. 2004; Burkhard et al. 2006; Michard et al. 2010). After the Variscan orogeny, the inherited Precambrian and Paleozoic structures were supposedly reactivated during Late Mesozoic-Cenozoic times, contemporaneously with the deformation and uplift of the Atlas Mountains to the north (Malusà et al. 2007; Sebti et al. 2009; Frizon De Lamotte et al. 2009; Soulaimani et al. 2014).

\section{Analytical methods}

Samples were collected from the intrusive Precambrian rocks exposed in the western (Kerdous inlier), central
(Agadir-Melloul, Zenaga, and West Saghro inliers), and eastern (East Saghro and Ougnat inliers) Anti-Atlas belt (see Fig. 2; Table 1). The samples were processed and analyzed for AFT and (U-Th)/He at the geochronology laboratory of the VU University of Amsterdam.

\section{Mineral separation}

In order to extract apatite grains, the rock samples were split into small pieces using a large hydraulic rocksplitter. The pieces were then crushed in a jaw-crusher, then in a disk mill. The crushed samples were sieved in a sieve machine to separate the fraction smaller than $250 \mu \mathrm{m}$, which is deslimed in a wet sieve system to remove everything that is $<32 \mu \mathrm{m}$ and dried in the oven at $50{ }^{\circ} \mathrm{C}$. The obtained 250-32 $\mu \mathrm{m}$ powder was further processed by heavy liquid and overflow centrifuge to separate the minerals based on their densities. Since the average apatite density is around $3.19 \mathrm{~g} / \mathrm{cm}^{3}$, grains with densities lower than 3.12 and higher than $3.33 \mathrm{~g} / \mathrm{cm}^{3}$ were separated from the rest. Finally, the latter fraction $\left(3.12<\rho<3.33 \mathrm{~g} / \mathrm{cm}^{3}\right)$ went through a Frantz magnet to separate magnetizable and non-magnetizable minerals. At this stage, the non-magnetizable fraction contains mostly apatites.

\section{Apatite fission track (AFT) methodology}

Apatite crystals were mounted in epoxy along with six zircon minerals aligned along a diagonal. The mounts were grinded and polished to reveal the internal surface of the apatites and then exposed to $5.5 \mathrm{M} \mathrm{NHO}_{3}$ for $20 \mathrm{~s}$ at room temperature to reveal fission tracks caused by the spontaneous fission of ${ }^{238} \mathrm{U}$. The external detector method was applied by placing low $U$ micas on top of the apatite mounts, and the samples were sent to the FRM II research reactor in Garching (Germany) for irradiation, along with dosimeter glasses, $\mathrm{CN}-5$, of known uranium content for the determination of the thermal neutron flux. After irradiation, 
the mica sheets were removed from the apatite mounts and the dosimeter glasses, and etched for $12 \mathrm{~min}$ and then $25 \mathrm{~min}$ in acid solution, $48 \% \mathrm{HF}$, at room temperature to make the induced tracks visible under optical microscope. Fission track densities, lengths and Dpar (fission track diameter) were measured in apatite grains with internal surfaces parallel to the $\mathrm{C}$-axis, using $1520 \times$ magnification with a $100 \times$ dry objective and the FTStage 4 upgrade program (Dumitru 1993). Dpar, long axes of FT etch-pits, is a rough proxy for the chemical composition of apatite and therefore for the annealing properties (Donelick et al. 1999). Since the ${ }^{235} U /{ }^{238} U$ ratio is constant, the number of induced tracks is proportional to the concentration of ${ }^{235} \mathrm{U}$ in the apatites and applied thermal neutron flux. Fission track ages have been calculated with TRACKKEY software (Dunkl 2002), using a zeta value of $358 \pm 10$ for apatite and $\mathrm{CN}-5$ glass. Fish canyon tuff and Durango apatites were used as age standards to determine the Zeta factor (Hurford and Green 1983).

\section{Apatite (U-Th)/He (AHe) methodology}

Two to four apatites crystal (aliquots) of each sample were hand-picked to obtain the best suitable aliquots to be dated. (U/Th)He dating was accomplished at the noble gas laboratory of the VU University of Amsterdam. It is a two-step process that involves Helium extraction and the determination of $U$ and Th concentrations using ICP-MS technique.

First, each single apatite crystal goes through a Helium extraction line equipped with laser and mass spectrometer. The apatite crystal is heated by laser up to $950{ }^{\circ} \mathrm{C}$ to release the $\mathrm{He}$, which is then expanded into the mass spectrometer, where $\mathrm{He}$ abundance is measured as counts per second and converted to ccSTP $\left(\mathrm{cm}^{3}\right.$ in standard temperature and pressure) using an internal standard.

After He extraction, the apatite crystal is unloaded and cleaned in a 7-ml Teflon beaker filled with MilliQ water. Then, the sample is spiked with calibrated ${ }^{229} \mathrm{Th}-{ }^{233} \mathrm{U}$ solution $\left({ }^{233} \mathrm{U} /{ }^{229} \mathrm{Th}=0.96\right)$ and dissolved by adding ten drops of $\mathrm{HNO}_{3}$ and ten drops of concentrated HF. The beaker is placed on a hotplate at $120^{\circ} \mathrm{C}$ for $48 \mathrm{~h}$. Finally, the solution is transferred to an ICP-MS tube for determination of the $\mathrm{U}$ and Th concentrations.

\section{Results}

\section{Apatite fission track (AFT) ages}

AFT analytical data are listed in Table 2. Most of the samples provided excellent measurements, with at least 15 grain ages and around 100 confined track lengths, except

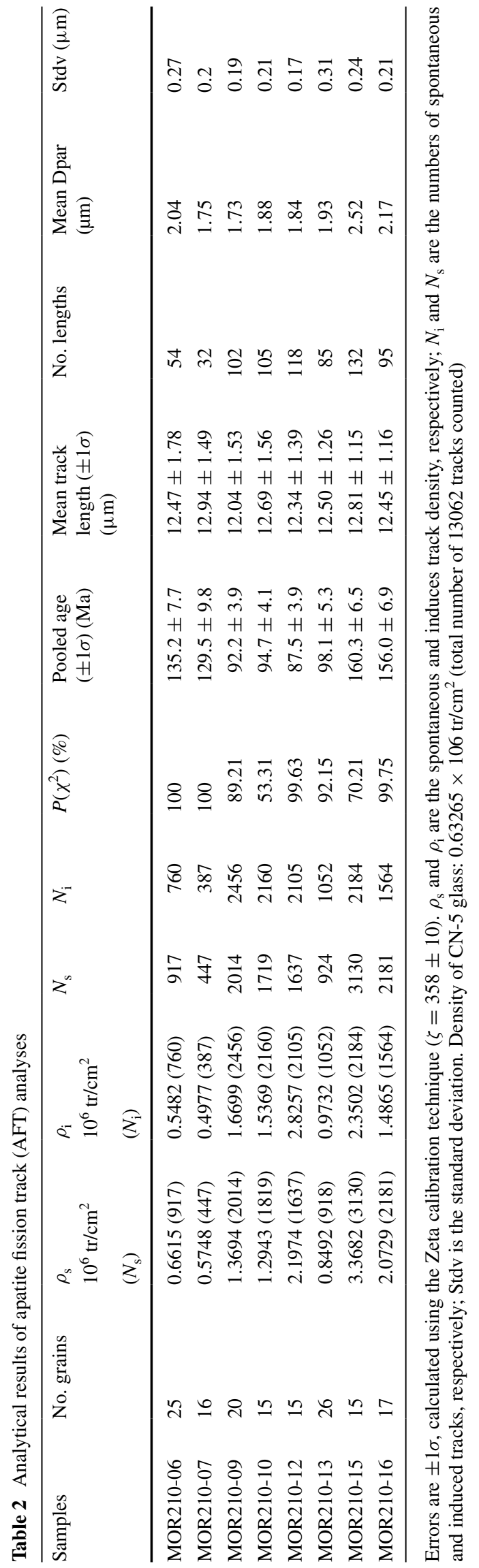


samples MOR210-06 and MOR210-07 where only 54 and 32 track lengths were measured, respectively.

The obtained pooled AFT ages are between $87.5 \pm 3.9$ and $160.3 \pm 6.5 \mathrm{Ma}$, and the mean track lengths (MTL) are between $12.04 \pm 1.53$ and $12.94 \pm 1.49 \mu \mathrm{m}$. The radial plots, shown in Fig. 4, indicate that single grain ages are clustered around the central age of each sample, with mean Dpar values ranging between 1.73 and $2.52 \mu \mathrm{m}$ and a standard deviation $<0.3 \mu \mathrm{m}$.

The oldest pooled AFT ages are found in the easternmost inliers of the Anti-Atlas, in East Saghro and Ougnat, which yield ages of $160.3 \pm 6.5$ and $156.0 \pm 6.9 \mathrm{Ma}$, respectively, and MTL of $12.81 \pm 1.15$ and $12.45 \pm 1.16 \mu \mathrm{m}$, respectively. The youngest pooled AFT ages are from the central inliers of Agadir-Melloul and Zenaga, located just south of the AAMF revealing ages between $94.7 \pm 4.1$ and $87.5 \pm 3.9 \mathrm{Ma}$, respectively and MTL of $12.69 \pm 1.56$ and $12.34 \pm 1.39 \mu \mathrm{m}$. The westernmost inlier of Kerdous shows pooled AFT intermediate age of $135.2 \pm 7.7$ and $129.5 \pm 9.8 \mathrm{Ma}$ with MTL of $12.47 \pm 1.78$ and $12.94 \pm 1.49 \mu \mathrm{m}$, respectively. Apart from the Kerdous samples, the MTL distribution in the other samples is relatively narrow (Fig. 4; Table 2) with no lengths smaller than $8 \mu \mathrm{m}$ and abundant long tracks, indicative of fast cooling through the apatite partial annealing zone (APAZ) and subsequent long residence time at low temperatures with very slow annealing at shallow depths near the surface (Ghorbal et al. 2008). This does not exclude processes causing subsidence and exhumation, as the AFT system is not sensitive enough to record these near surface dynamic processes, while apatite $(\mathrm{U}-\mathrm{Th}) / \mathrm{He}$ does.

\section{Apatite (U-Th)/He ages}

The uncorrected $(\mathrm{U}-\mathrm{Th}) / \mathrm{He}(\mathrm{AHe})$ ages range between $20.78 \pm 2$ and $125 \pm 12.24 \mathrm{Ma}$, whereas the ages corrected for $\alpha$-ejection are between $27.23 \pm 2.62$ and $156.31 \pm 15.29$ Ma (Table 3). Samples MOR210-06, MOR210-09, MOR210-12, MOR210-14, and MOR21015 show an excellent AHe age reproducibility within error in all the analyzed aliquots (Table 3). Three samples show only partial AHe age reproducibility within error from three aliquots out of four in MOR210-10 and MOR210-16, and from two aliquots out of three in MOR210-17 (Table 3). Samples MOR210-07 and MOR210-13 show extremely poor AHe age reproducibility (Table 3). Poor AHe age replication within the same sample could be attributed to analytical error during the $\mathrm{He}$ extraction, or more likely to the presence of undetected fluid and/or mineral inclusions in the analyzed apatite aliquot.

Samples from neighboring outcrops, in the AgadirMelloul and Ougnat inliers, show consistent $\mathrm{AHe}$ ages which cluster around $71.79 \mathrm{Ma}$ (mean corrected age with a standard deviation (Stdv) of $4.8 \%$ ) and $44.19 \mathrm{Ma}$ $(\operatorname{Stdv}=13.8 \%)$, respectively. This is not the case in the Saghro inlier where the contiguous samples MOR210-14 and MOR210-15 produce mean corrected $\mathrm{AHe}$ ages of $54.12 \mathrm{Ma}(\operatorname{Stdv}=5.5 \%)$ and $112.91 \mathrm{Ma}(\operatorname{Stdv}=1.11 \%)$, respectively.

Most of the samples show corrected AHe ages that are 15-110 Myr younger than the AFT ages, except samples MOR210-07 and MOR210-13, which have poor AHe age duplicability and show corrected AHe ages older than AFT ages. For both reasons, poor reproducibility and AHe ages being older than AFT ages, the AHe apparent ages of MOR210-07 and MOR210-13 are not further discussed. The observed overall trend shows $\mathrm{AHe}$ ages becoming younger moving eastwards, away from the Atlantic margin. Thereby, in the West and Central Anti-Atlas, a mean (corrected) AHe age of $112.37 \mathrm{Ma}$ is found in the Kerdous inlier (MOR210-06), 71.79 Ma in the Agadir-Melloul inlier, and 51.81 Ma in the Zenaga inlier. In the East AntiAtlas, the East Saghro inlier shows a significant variability in AHe ages, but the younger ages are from MOR21014 which shows a mean AHe age of $45.12 \mathrm{Ma}$, which is comparable to the mean AHe age of $44.19 \mathrm{Ma}$ found in the easternmost Ougnat inlier (MOR210-16 and MOR210-17).

The observed trend of the AHe ages is not compatible with the obtained AFT age distribution, pointing to a (partial) uncoupling of both low-temperature geochronometers in the later geological history. It supports the suggestion earlier made that apatite (U-Th)/He systematics may have been affected by late-stage subsidence and exhumation, not recorded by the apatite fission track system.

\section{Modeling the thermal history of the Anti-Atlas}

\section{The HeFTy modeling software}

Time-temperature $(t-T)$ modeling is achieved using the HeFTy software (Ketcham 2005), which uses AFT and AHe data to predict $t-T$ paths describing the thermal history of the analyzed samples.

The AFT modeling is based on the annealing model of Ketcham et al. (2007), and the input parameters consist of length data and age data. The length data include lengths of individual fission tracks, angle of the tracks to the crystallographic c-axis, and the measured Dpar values. The age data include the Zeta calibration method used and for each analyzed apatite grain, the number of spontaneous and induced tracks, and the mean Dpar value.

The AHe modeling utilizes the calibration parameters of Shuster et al. (2006), which takes as input the aliquot size, the U-Th content, and the uncorrected AHe age, and account for $\alpha$-ejection correction. 


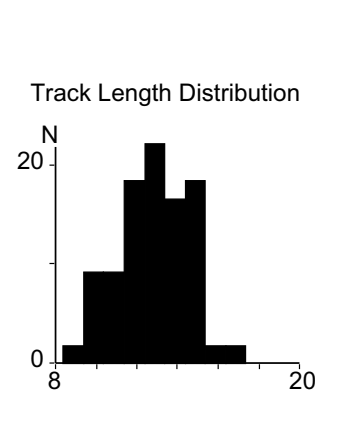

\section{MOR210-06}
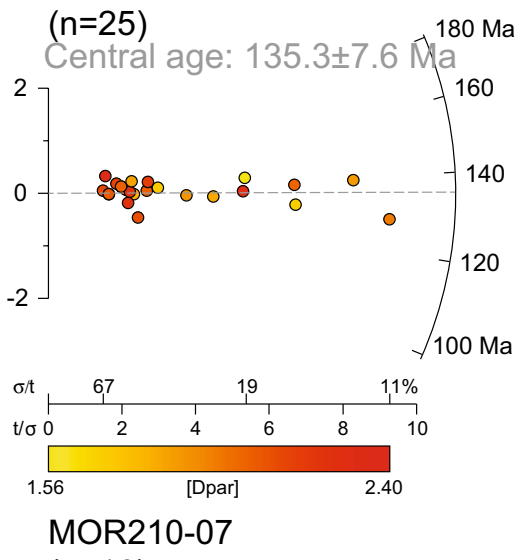

$(n=16)$

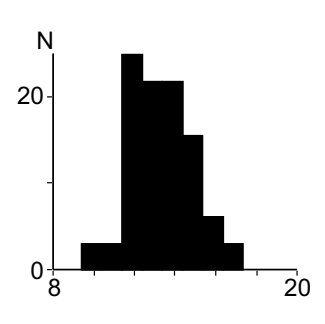

Central age: $129.6 \pm 9.7 \mathrm{M}$

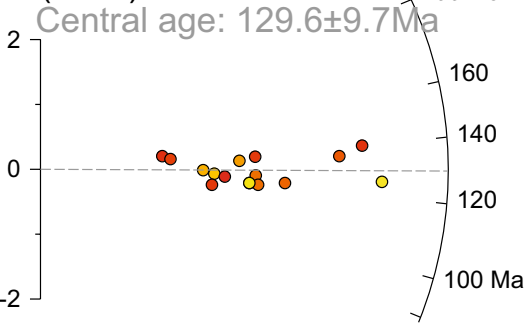

$\sigma / \mathrm{t}$

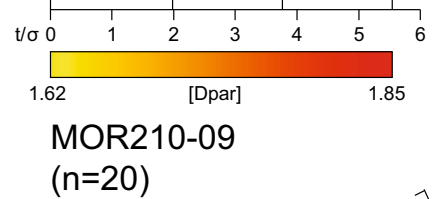

$(\mathrm{n}=20)$

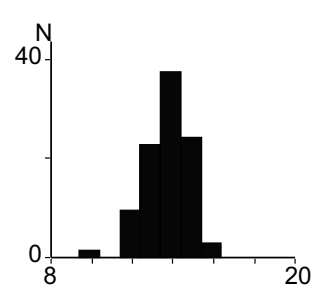

Centra
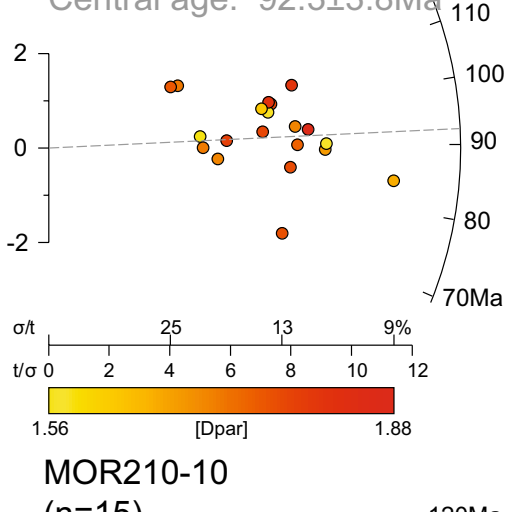

$(n=15)$

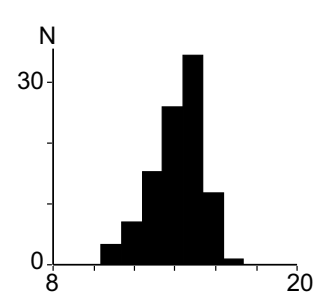

MOR210-12
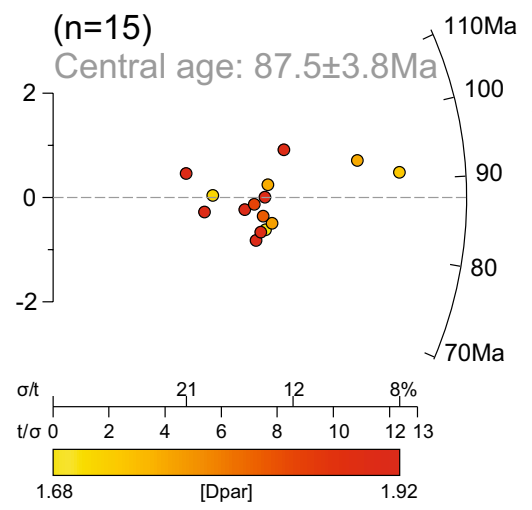

MOR210-13

$(\mathrm{n}=26)$

Central age: 98.8 $\pm 5.2 \mathrm{M}$
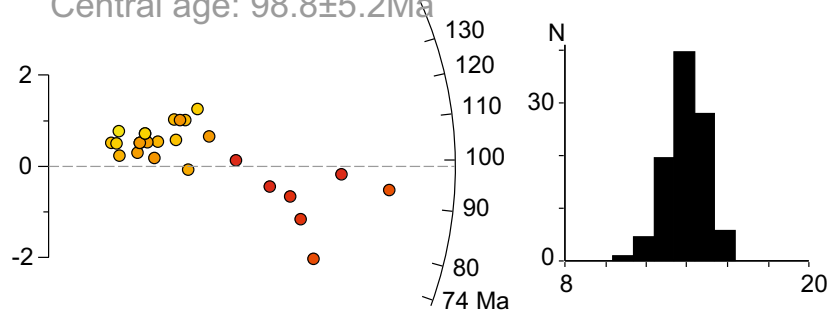

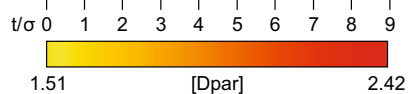

MOR210-15

$(n=15)$

Central age: $160.4 \pm 6.3 \hat{M}^{200} \mathrm{Ma}$
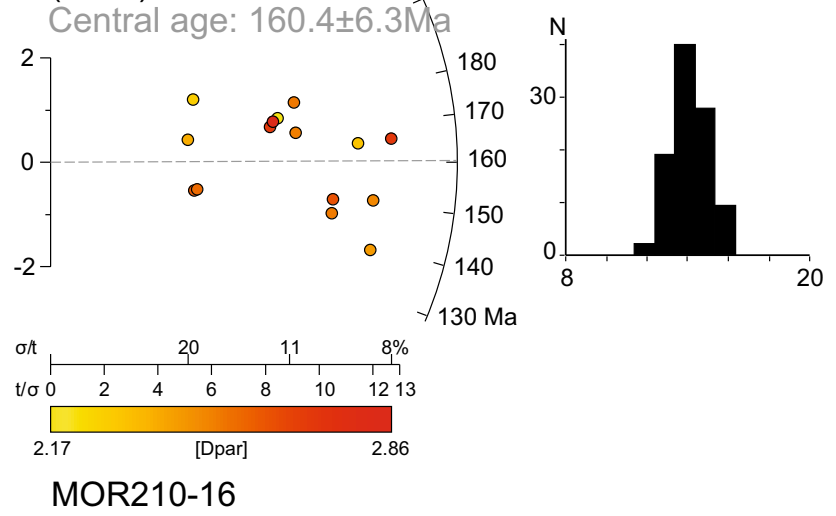

Central age: $156.1 \pm 5.2$ Ma $^{200}$
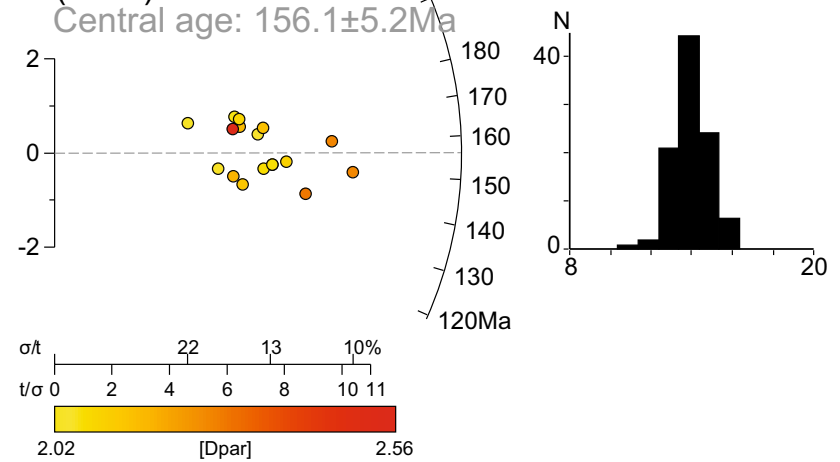

Fig. 4 Radial plots of single grain AFT ages for each of the samples and histograms with the distribution of the measured confined track lengths 


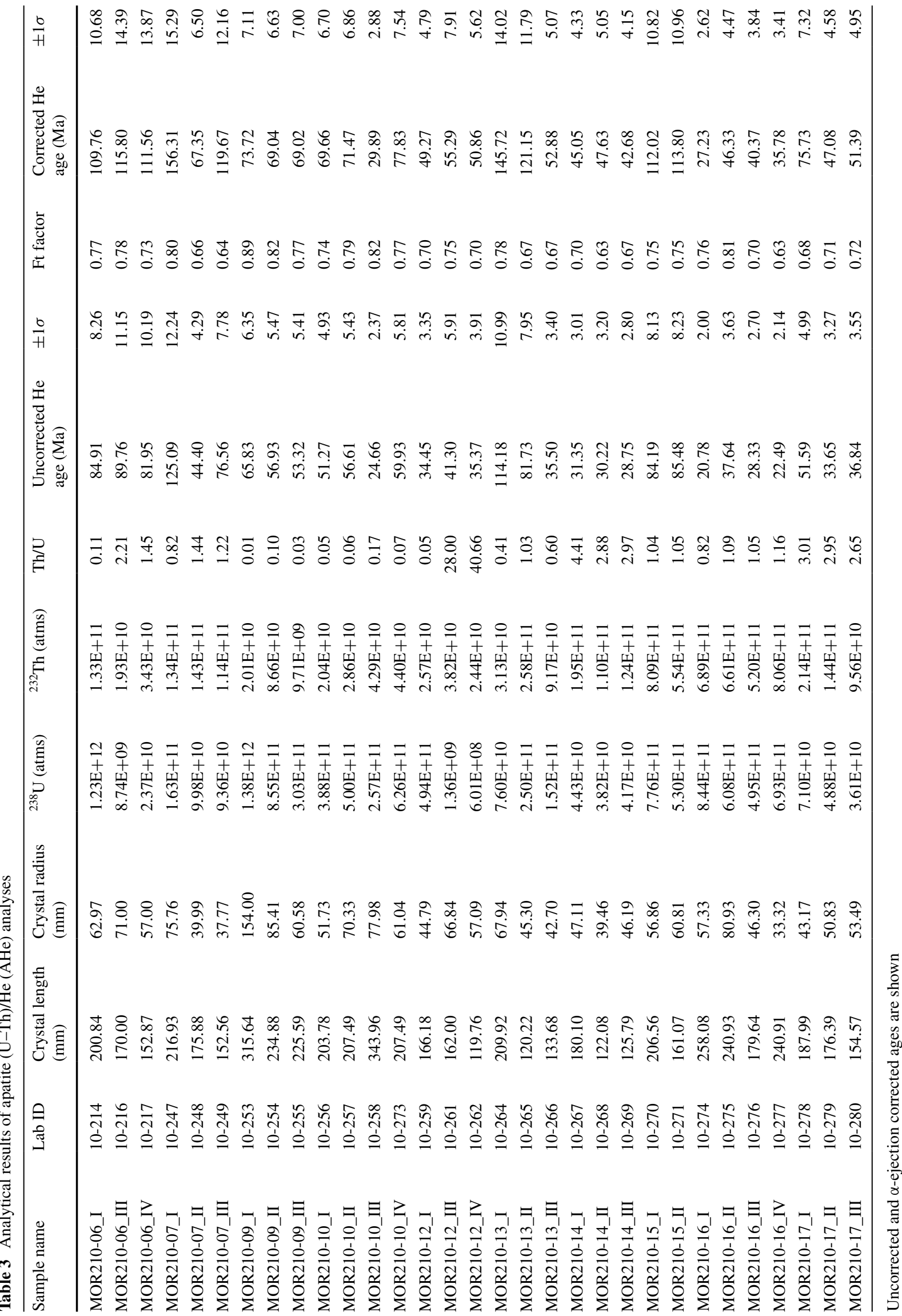


HeFTy consists of both forward and inverse modeling (Ketcham 2005). The forward model allows to manually predict $t-T$ paths that fit the data distribution. While the inverse models test random $t-T$ paths, using a Monte Carlo algorithm, to find the thermal history that best matches the input data. The latter mode requires constraint boxes, which are geological constraints imposed to the model.

HeFTy uses statistics to evaluates the quality of a given $t-T$ path, which are expressed by a value called goodnessof-fit (GOF) based on the Kolmogorov-Smirnov test or the Kuiper's Statistic (Press et al. 1996). GOF values, comprised between 0 (no fit) and 1 (perfect fit), are calculated for the fission track length distribution and for the AFT and AHe ages (see Ketcham 2005 for more details). A model is considered "acceptable" if all statistics' GOF are above 0.05 . It is considered "good" if the mean GOF value is at least 0.5 and the minimum GOF value is greater than $1 /$ $(N+1)$, where $N$ is the number of GOF tests (Ketcham 2005).

We model the post-Paleozoic thermal history of samples that have at least 85 track length measurements, with the exception of MOR210-06 with only 54 track length measured, and a good AHe age reproducibility. Thereby, six samples were modeled, namely, MOR210-06, MOR21009, MOR210-10, MOR210-12, MOR210-15, and MOR210-16, and the inverse modeling is set to be completed after the evaluation of one million random $t-T$ paths for each of the samples.

\section{Model constraints}

The thermal modeling is constrained by two boxes (A and B) derived from geological observations from the AntiAtlas belt and the surrounding domains and one box (C) based on the obtained AHe ages (Fig. 5).

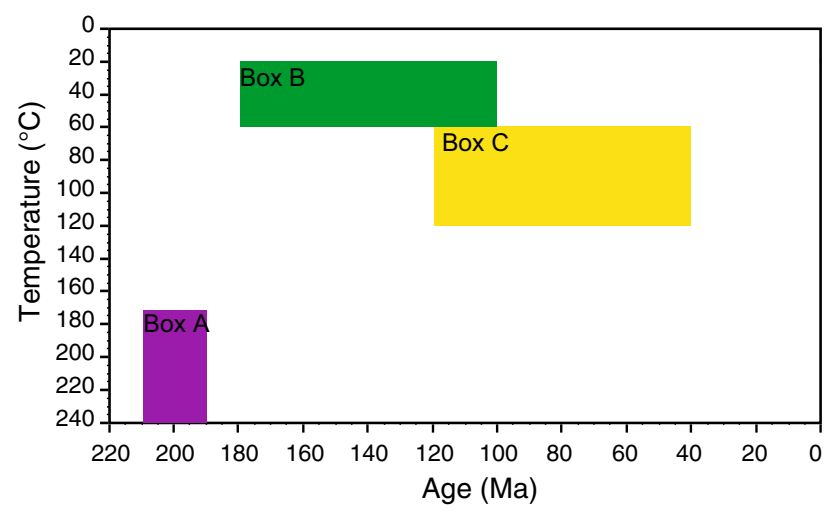

Fig. 5 Boxes used to constrain the HeFTy inverse modeling. Timetemperature ranges of Boxes A, B, and $C$ are 210-190 Ma, 240$170{ }^{\circ} \mathrm{C}$; $180-100 \mathrm{Ma}, 60-20{ }^{\circ} \mathrm{C}$; and $120-40 \mathrm{Ma}, 120-60{ }^{\circ} \mathrm{C}$; respectively
The first constraint (Box A) assumes that the presently outcropping basement was $8-11 \mathrm{~km}$ deep by the end of the Triassic (200 Ma). Two long basaltic dykes related to the Central Atlantic Magmatic Provinces (CAMP) are found cropping out in the Anti-Atlas (Fig. 2). The Foum Zguid dyke located south of Zenaga and Saghro inliers and the Igherm dyke which is located between the Kerdous and Agadir-Melloul inliers. Foum Zguid dyke produces a plagioclase ${ }^{40} \mathrm{Ar} /{ }^{39} \mathrm{Ar}$ age of $196.9 \pm 1.8 \mathrm{Ma}$ (Sebai et al. 1991; Touil et al. 2008), which is comparable with the overall age of the CAMP event which is estimated at $199.1 \pm 1 \mathrm{Ma}$ (Marzoli et al. 2004; Knight et al. 2004; Nomade et al. 2007; Verati et al. 2007). The Igherm dyke has not been dated but according to its geological setting; it is considered as coeval to the Foum Zguid dyke. Petrographic studies on Foum Zguid and Igherm dykes revealed, based on hornblende-Al content, that the crystallization depth is between 8 and $11 \mathrm{~km}$ (Aarab et al. 1994; Youbi et al. 2003; Touil et al. 2008). Given the extent of the Igherm and Foum Zguid dykes, approximately 100 and $160 \mathrm{~km}$ long respectively, and their proximity to the sampled outcrops, we assume that these dykes and the surrounding PrecambrianPaleozoic rocks were exhumed at the same time.

The second constraint (Box B) assumes that the basement was at shallow depth sometime between the Middle Jurassic and the Early Cretaceous (180-100 Ma). Terrigenous sediments are found unconformably overlying the Precambrian and Paleozoic basement in many locations around the Anti-Atlas; in Sidi Ifni to the west, in the Siroua inlier and the Ouarzazate basin to the north, and in the Guir Hamada on the eastern edge of the belt (Hollard et al. 1985; Zouhri et al. 2008). These sediments were poorly dated and assumed to be Lower Cretaceous but could be as old as Upper Jurassic or even Triassic.

We added a third constraint (Box C) between the Early Cretaceous and the Eocene (120-40 Ma) to enable the $t-T$ path to re-enter the partial annealing zone of AFT and no retention zone of the AHe system. This box is necessary because our sensitivity modeling experiments showed that HeFTy tends to only test paths that run close to the surface between Box B and the present day, ignoring the AHe ages.

\section{Modeling results}

The inverse modeling, constrained by boxes A, B, and C, succeeded in finding excellent $t-T$ paths that honor both the AFT and AHe data (Fig. 6). The results indicate a common trend along the entire Anti-Atlas belt, which is characterized by two cooling phases separated by a heating phase during the Mesozoic and Cenozoic (Fig. 6).

The first cooling event brought the Anti-Atlas basement from deep temperatures of $240-190{ }^{\circ} \mathrm{C}$ to shallow temperatures of $60-25^{\circ} \mathrm{C}$. It started around the same time by the 
end of the Triassic (210-190 Ma) and ended at variable times in the different domains of the belt. Since our modeling experiments only capture the post-Paleozoic evolution of the Anti-Atlas, this cooling could have initiated much earlier than it is showed by our models. The best-fit $t-T$ paths show a rapid initial cooling phase in the AgadirMelloul, E Saghro, and Ougnat that ended around $180 \mathrm{Ma}$ (Fig. 6b, c, e, f), whereas it continued much longer in the
Kerdous and Zenaga inliers (Fig. 6a, d) where it ended around 150 and $160 \mathrm{Ma}$, respectively. Immediately after this first cooling event, the basement rocks of the western and central inliers (Kerdous, Agadir-Melloul, and Zenaga) were heated again and reached temperatures ranging between 85 and $115^{\circ} \mathrm{C}$ around 120-105 Ma (Fig. 6a-d). However, in the eastern Anti-Atlas, the basement of the E Saghro remained stable around $40{ }^{\circ} \mathrm{C}$ for more than (a) MOR210-06 (Kerdous inlier)

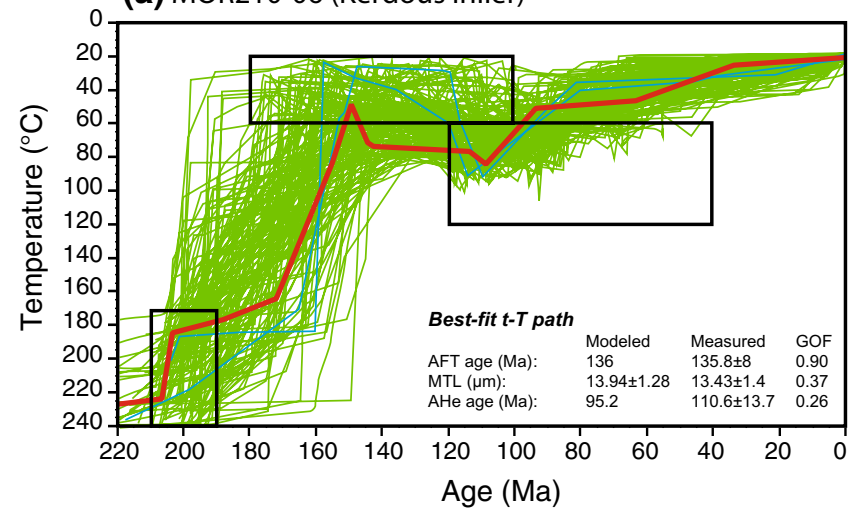

(c) MOR210-10 (Agadir-Melloul inlier)

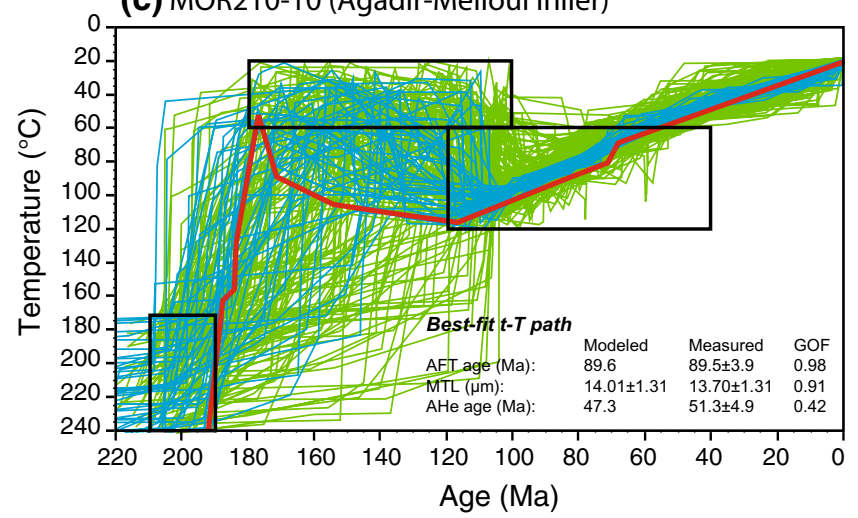

(e) MOR210-15 (E Saghro inlier)

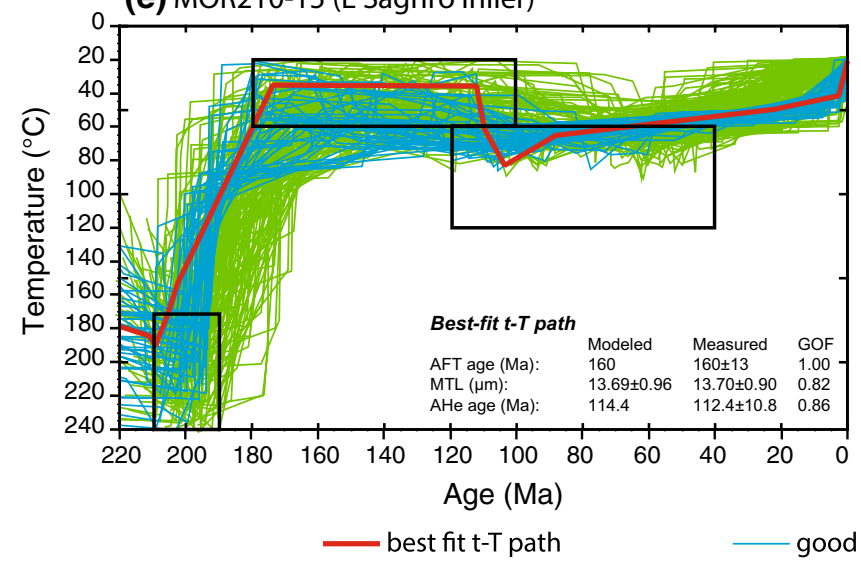

(b) MOR210-09 (Agadir-Melloul inlier)

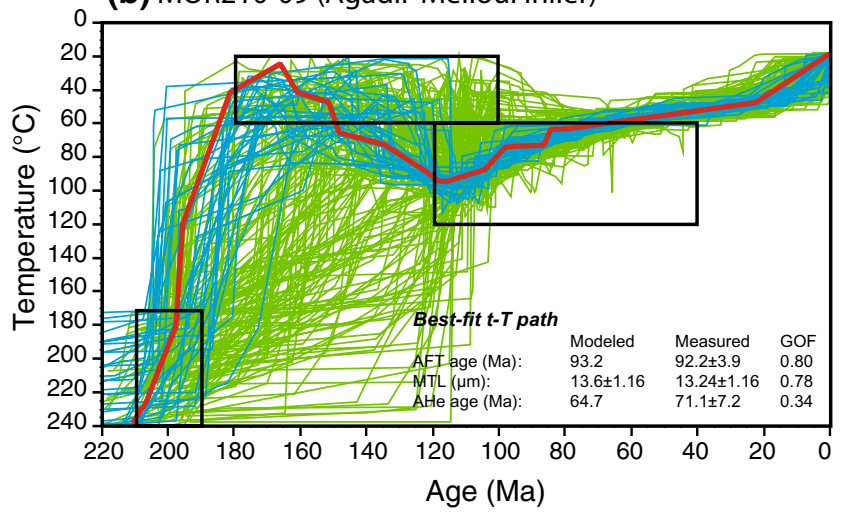

(d) MOR210-12 (Zenaga inlier)

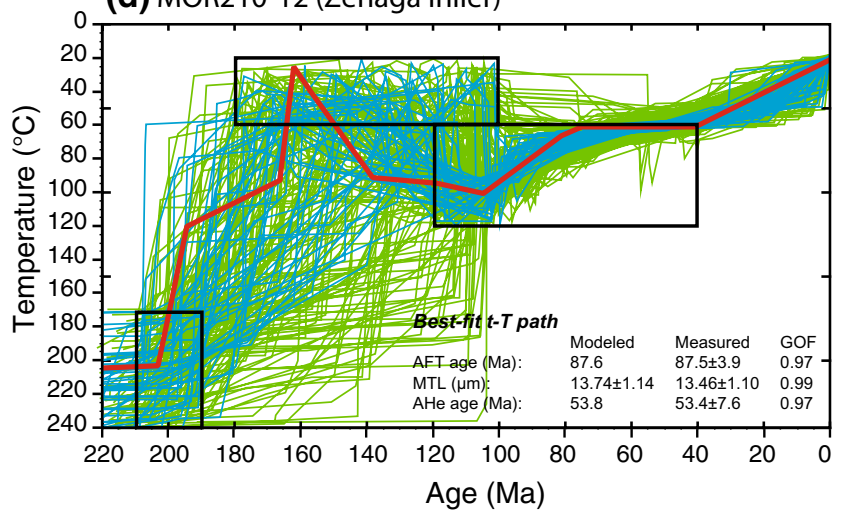

(f) MOR210-16 (Ougnat)

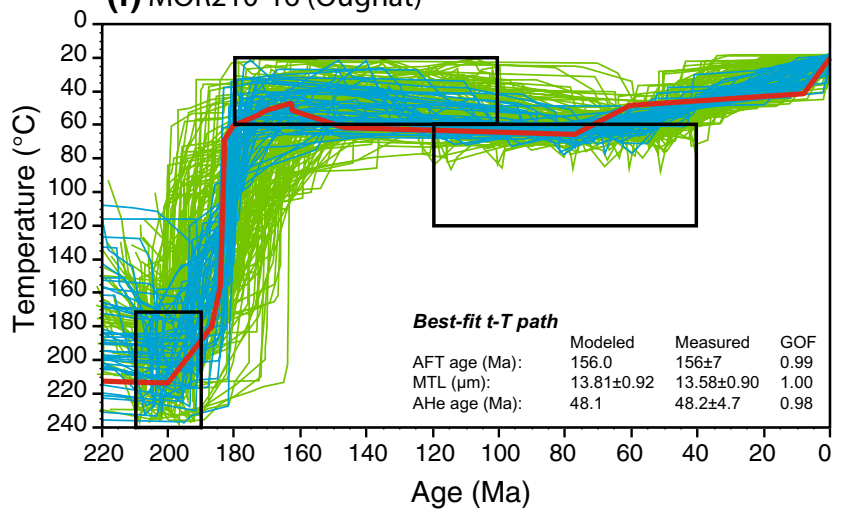

Fig. 6 Inverse time-temperature $(t-T)$ models obtained using AFT and AHe data, and the constraint boxes A, B, and C shown in Fig. 4. The statistically acceptable $t-T$ paths are shown in green, the statically good $t-T$ paths are shown in cyan, and the best-fit $t-T$ paths are shown in red 
$60 \mathrm{Ma}(174-112 \mathrm{Ma})$ before experiencing a rapid (112$103 \mathrm{Ma}) 40{ }^{\circ} \mathrm{C}$ heating event (Fig. 6e), while the Ougnat inlier underwent a very slow and prolonged (160-80 Ma) heating event of only $15{ }^{\circ} \mathrm{C}$ (Fig. 6f). The final cooling phase, which placed the basement rocks at surface temperature $\left(\sim 20{ }^{\circ} \mathrm{C}\right)$, was much slower than the first one as it lasted much longer (120-0 Ma) in all the examined samples.

\section{Comparing our results to previous low-temperature geochronological studies}

Table 4 shows a compilation of the various low-temperature geochronology ages reported in the Anti-Atlas (Malusà et al. 2007; Ghorbal 2009; Sebti et al. 2009; Sebti 2011; Ruiz et al. 2011; Oukassou et al. 2013; Sehrt 2014), while Fig. 7 shows these ages projected longitudinally along an E-W axis.

Overall, our AFT and AHe ages compare fairly well with the other published data. Keeping in mind, the temperature window constrained by each method [ZFT: 270$210{ }^{\circ} \mathrm{C}$ (Brandon et al. 1998); ZHe: $200-160{ }^{\circ} \mathrm{C}$ (Reiners et al. 2005); AFT: $120-70{ }^{\circ} \mathrm{C}$ (Green et al. 1989); AHe: $75-45{ }^{\circ} \mathrm{C}$ (Farley 2000)], it appears that the entire AntiAtlas belt experienced substantial cooling from the Paleozoic until the Neogene. However, the AHe ages get younger as we move east, indicating that the basement in the central and eastern domains reached temperatures below the He partial resetting window (i.e., $<45^{\circ} \mathrm{C}$ ) $60-40 \mathrm{Myr}$ later than in the western domain.

The modeled $t-T$ paths, displayed in Fig. 8, show many similarities with our modeling results, especially in Mesozoic time. They illustrate a thermal evolution which is also characterized by two cooling periods separated by a heating event in the western and central Anti-Atlas (Fig. 8a, b) and by a continuous cooling phase in the eastern Anti-Atlas (Fig. 8c). However, major discrepancies are noted in the timing and rates of each thermal event. For instance, Ruiz et al. (2011) predict the heating event in the western inliers to be 50-60 Myr younger than in our models (Fig. 8a). In the eastern domain, Malusà et al. (2007) propose a post-Triassic thermal evolution characterized by a continuous cooling with low cooling rates during the Mesozoic and high cooling rates during the Cenozoic, and no heating event as showed in our models (Fig. 8c).

The discrepancies between the different thermal histories result mainly from the inconsistencies in the constraints imposed to the models. While our models account for both AFT and AHe data, most of the published $t-T$ paths rely solely on FT data (except MA-12 and MA-15 from Sehrt (2014)). Moreover, all the published models ignore the nearby CAMP dykes which are documented to be $8-11 \mathrm{~km}$ deep by the end of the Triassic (Touil et al. 2008; Silva et al. 2010).

\section{Discussion}

The cooling and heating events documented by the various AFT and AHe data from the Anti-Atlas (Fig. 8) are interpreted to be related to crustal exhumation/denudation and subsidence/sedimentation respectively. Hereafter, we attempt to quantify these post-Variscan vertical movements affecting the Anti-Atlas and investigate the related tectonic processes.

\section{Evolution of surface heat flow and geothermal gradient along the Anti-Atlas domain}

Quantifying the amounts and rates of vertical movement requires estimations of surface heat flow which is the expression of the geothermal gradient at depth (Ehlers 2005). The few surface heat flow measurements available in the Anti-Atlas are from $200 \mathrm{~m}$ deep drill-holes from the Bou-Azzer mine in the central part of the belt (Rimi 1990, 1999). They show very low surface heat flow values ranging from 36 to $40 \mathrm{mWm}^{-2}$. Other measurements from neighboring domains indicate higher values in the Atlantic continental shelf and the coastal basin to the west of the Anti-Atlas $\left(74-76 \mathrm{mWm}^{-2}\right)$, and in the Tindouf basin to the south $\left(86.5 \pm 14 \mathrm{mWm}^{-2}\right)$ (Rimi 1990, 1999). These values reflect the present-day thermal state of the crust, whereas on the scale of the Anti-Atlas belt, which is of hundreds of kilometers, variations in continental heat flow, thus in thermal gradient, are expected to occur over space and time. Variation in heat flow is typically related to the active tectonic processes such as lithospheric extension, sedimentation, erosion, and magmatism.

During the Late Triassic-Early Jurassic, the Anti-Atlas domain was flanked by two rift systems, the Tethyan Atlas rift in the north (Beauchamp 1988; Beauchamp et al. 1999; Frizon De Lamotte et al. 2009) and the Atlantic rift in the west (Favre and Stampfli 1992; Davison 2005; Gouiza 2011). Present-day observations indicate that active rifts undergoing crustal extension and their flanking regions are characterized by high $\left(107-92 \mathrm{mWm}^{-2}\right)$ to moderate (73-52 $\mathrm{mWm}^{-2}$ ) surface heat flow, respectively (Fig. 9; Pollack and Chapman 1977; Vitorello and Pollack 1980; Kusznir and Park 1987). Following break-up and initiation of lithospheric cooling, continental heat flow is supposed to decrease exponentially with time and is believed to reach equilibrium around $35-40 \mathrm{mWm}^{-2}$ after $300-400 \mathrm{Myr}$ 
Table 4 Compilation of low-T geochronology ages from this work and previous works obtained from samples along the Anti-Atlas belt

\begin{tabular}{|c|c|c|c|c|c|c|c|c|c|}
\hline & \multirow[t]{2}{*}{ Sample } & \multicolumn{2}{|l|}{$\mathrm{AFT}$} & \multicolumn{2}{|l|}{$\mathrm{AHe}$} & \multicolumn{2}{|l|}{ ZFT } & \multicolumn{2}{|l|}{$\mathrm{ZHe}$} \\
\hline & & Age (Ma) & Error & Age (Ma) & Error & Age (Ma) & Error & Age (Ma) & Error \\
\hline \multicolumn{10}{|l|}{ Ifni inlier } \\
\hline \multirow[t]{2}{*}{ Sebti et al. (2009) } & GDI3 & & & & & 326.5 & 37 & & \\
\hline & GDI4 & & ' & & & 337.9 & 35 & & \\
\hline \multirow[t]{2}{*}{ Ruiz et al. (2011) } & GM1 & 140.5 & $18(2 \sigma)$ & & & & & & \\
\hline & GDI3 & 120.7 & $16.2(2 \sigma)$ & & & & & & \\
\hline \multirow[t]{5}{*}{ Sebti (2011) } & GALLO 2 & 177.1 & 15.2 & & & & & & \\
\hline & GDIF1 & 188.8 & 14.95 & & & & & & \\
\hline & GDLS1 & 179 & 12.18 & & & & & & \\
\hline & MGRM1 & 184.5 & 12.49 & & & & & & \\
\hline & MGRM2 & 168.8 & 11.04 & & & & & & \\
\hline \multirow[t]{4}{*}{ Sehrt (2014) } & MA-20 & 175.3 & 13.9 & 119.8 & 7.2 & & & 261.6 & 3.6 \\
\hline & MA-21 & 181.8 & 12.3 & 164.1 & 9.8 & & & 173.2 & 4.7 \\
\hline & MA-22 & 189.1 & 14.3 & - & - & & & & \\
\hline & MA-23 & 218.5 & 17.4 & - & - & & & & \\
\hline \multicolumn{10}{|l|}{ Kerdous inlier } \\
\hline \multirow[t]{8}{*}{ Sebti et al. (2009) } & AGCHTIM & & & & & 358 & 31 & & \\
\hline & TAF7 & & & & & 326.3 & 20 & & \\
\hline & TAF9 & & & & & 328.6 & 23 & & \\
\hline & TAF12 & & & & & 327.5 & 31 & & \\
\hline & TAF15 & & & & & 319.3 & 32 & & \\
\hline & TAF20 & & & & & 323.7 & 24 & & \\
\hline & TAF21 & & & & & 324.5 & 38 & & \\
\hline & TAF22 & & & & & 336 & 29 & & \\
\hline \multirow[t]{8}{*}{ Ruiz et al. (2011) } & TAF3 & 150.9 & $30.6(2 \sigma)$ & & & & & & \\
\hline & TAF6 & 169.5 & $37.2(2 \sigma)$ & & & & & & \\
\hline & TAF7 & 144.1 & $22(2 \sigma)$ & & & & & & \\
\hline & TAF9 & 159.8 & $28.2(2 \sigma)$ & & & & & & \\
\hline & TAF13 & 143.4 & $21.8(2 \sigma)$ & & & & & & \\
\hline & TAF14 & 167.9 & $32.2(2 \sigma)$ & & & & & & \\
\hline & TAF16 & 164.4 & $38(2 \sigma)$ & & & & & & \\
\hline & TAF22 & 173.3 & $45(2 \sigma)$ & & & & & & \\
\hline \multirow[t]{10}{*}{ Sehrt (2014) } & MA-08 & 154.7 & 12.2 & - & - & 298.6 & 30.6 & - & - \\
\hline & MA-09 & 125.8 & 13.5 & 88.7 & 5.3 & & & & \\
\hline & MA-10 & 169 & 11.5 & - & - & 311.4 & 22 & - & - \\
\hline & MA-11 & 165.9 & 15.7 & - & - & & & & \\
\hline & MA-12 & 180.7 & 11.7 & 88.2 & 5.3 & - & - & 133.2 & 27.5 \\
\hline & MA-13 & 150.3 & 11.6 & 88.7 & 5.3 & & & & \\
\hline & MA-14 & 155.2 & 10.4 & 55.7 & 3.3 & 303.6 & 27 & 211.1 & 3.1 \\
\hline & MA-15 & 171.4 & 11.3 & 61 & 3.7 & & & & \\
\hline & MA-16 & 119.7 & 13.4 & - & - & & & & \\
\hline & MA-17 & 139 & 9.1 & 123.1 & 7.4 & 287.1 & 23 & 194 & 3 \\
\hline \multicolumn{10}{|l|}{ Igherm inlier } \\
\hline \multirow[t]{5}{*}{ Ruiz et al. (2011) } & 06GR20 & & & 89.6 & 3 & & & 234.4 & 18.8 \\
\hline & 06GR19 & & & 58.4 & 0.8 & & & 199.9 & 16 \\
\hline & 06GR18 & & & 148.1 & 1.5 & & & 192.8 & 15.4 \\
\hline & 06GR17 & & & 97.5 & 1.2 & & & & \\
\hline & 06GR16 & & & 103.7 & 4.2 & & & 248.4 & 19.9 \\
\hline
\end{tabular}


Table 4 continued

\begin{tabular}{|c|c|c|c|c|c|c|c|c|c|}
\hline & \multirow[t]{2}{*}{ Sample } & \multicolumn{2}{|l|}{ AFT } & \multicolumn{2}{|l|}{$\mathrm{AHe}$} & \multicolumn{2}{|l|}{ ZFT } & \multicolumn{2}{|l|}{$\mathrm{ZHe}$} \\
\hline & & Age (Ma) & Error & Age (Ma) & Error & Age (Ma) & Error & Age (Ma) & Error \\
\hline \multirow[t]{5}{*}{ Sehrt (2014) } & MA-01 & 168.4 & 10.6 & - & - & - & - & 87.8 & 2 \\
\hline & MA-02 & 163.5 & 11.5 & - & - & & & & \\
\hline & MA-03 & 169 & 17.1 & 85.4 & 5.1 & 330.6 & 23.8 & - & - \\
\hline & MA-04 & 174.6 & 13.5 & - & - & & & & \\
\hline & MA-06 & 149.6 & 13.5 & 49 & 2.9 & 310 & 18.9 & - & - \\
\hline \multicolumn{10}{|l|}{ Siroua inlier } \\
\hline \multirow[t]{5}{*}{ Ghorbal (2009) } & SI.04.01 & 96.5 & 5 & 36.1 & 1.6 & & & & \\
\hline & SI.04.02 & 128.4 & 4.6 & 50.4 & 3.3 & & & & \\
\hline & SI.04.03 & - & - & 36.2 & 1.7 & & & & \\
\hline & SI.04.04 & 146.6 & 2 & 54.5 & 1.3 & & & & \\
\hline & SI.04.05 & 144.9 & 1.8 & 58.1 & 1.3 & & & & \\
\hline \multicolumn{10}{|l|}{ Bou-Azzer inlier } \\
\hline \multirow[t]{9}{*}{ Oukassou et al. (2013) } & BA2 & 144 & 9 & & & & & & \\
\hline & BA5 & 171 & 7 & & & 316 & 26 & & \\
\hline & BA6 & 168 & 7 & & & & & & \\
\hline & BA7 & 137 & 7 & & & 337 & 21 & & \\
\hline & BA8 & 134 & 7 & & & 306 & 20 & & \\
\hline & BA10 & 156 & 10 & & & & & & \\
\hline & BA14 & 153 & 10 & & & 340 & 20 & & \\
\hline & BA15 & 153 & 5 & & & 314 & 21 & & \\
\hline & BA16 & 154 & 10 & & & 316 & 21 & & \\
\hline \multicolumn{10}{|l|}{ Saghro inlier } \\
\hline \multirow[t]{7}{*}{ Malusà et al. (2007) } & s1-mrc $10 / 05$ & 95.5 & 8.8 & & & & & & \\
\hline & s2-mrc 3/04 & 90.4 & 4.4 & & & & & & \\
\hline & s3-mrc 3/05 & 88 & 3.9 & & & & & & \\
\hline & s4-mrc 1/05 & 146.2 & 5.7 & & & & & & \\
\hline & s5-mrc 4/04 & 150.1 & 29.6 & & & & & & \\
\hline & s8-mrc 32/04 & 138.5 & 6.7 & & & & & & \\
\hline & s10-mrc 34/04 & 238.6 & 42 & & & & & & \\
\hline \multicolumn{10}{|l|}{ Ougnat inlier } \\
\hline \multirow[t]{3}{*}{ Malusà et al. (2007) } & s6-mrc 28/04 & 141.4 & 8.1 & & & & & & \\
\hline & s7-mrc $11 / 04$ & 140 & 11.7 & & & & & & \\
\hline & S9-mrc 2/05 & 216 & 11.4 & & & & & & \\
\hline
\end{tabular}

(e.g., Polyak and Smirnov 1968; England and Richardson 1980).

Erosion and sedimentation can impact the thermal structure of the crust (Ehlers 2005). Erosion increases temperatures in the crust by removing cold upper crustal material which is replaced by warmer mantle material, while sedimentation has the opposite effect, as the cool temperature of the deposited sediment is advected downward causing a net decrease in temperatures at depth (Ehlers 2005).

Intrusion of magmatic bodies can also perturb greatly the heat flow in the surrounding host rocks. However, the
Mio-Pliocene volcanism (ca. 11-3 Ma) recorded in the Siroua plateau (Berrahma and Delaloye 1989) and the Saghro inlier (Berrahma et al. 1993) appears to have no effect on the AFT and AHe ages. Moreover, Ehlers (2005) shows that magmatic intrusions which are $<1 \mathrm{~km}$ wide have a very limited impact, in space and time, on the geothermal gradient of the surrounding rocks.

Figure 10 shows the predicted variations of the geothermal gradient over time in the Anti-Atlas assuming an initial surface heat flow of $75 \mathrm{mWm}^{-2}$ during rifting time (ca. 220-175 Ma), which is comparable to the present-day value measured in the Atlantic continental shelf to the west of the 
Fig. 7 Compilation of low-T geochronology ages available in the Anti-Atlas from the literature and the present work, projected longitudinally on an E-W axis. CAMP Central Atlantic Magmatic Province

Fig. 8 Comparison between the best-fit $t-T$ paths (obtained from apatite and zircon analyses) published in the literature and the ones obtained in the present work

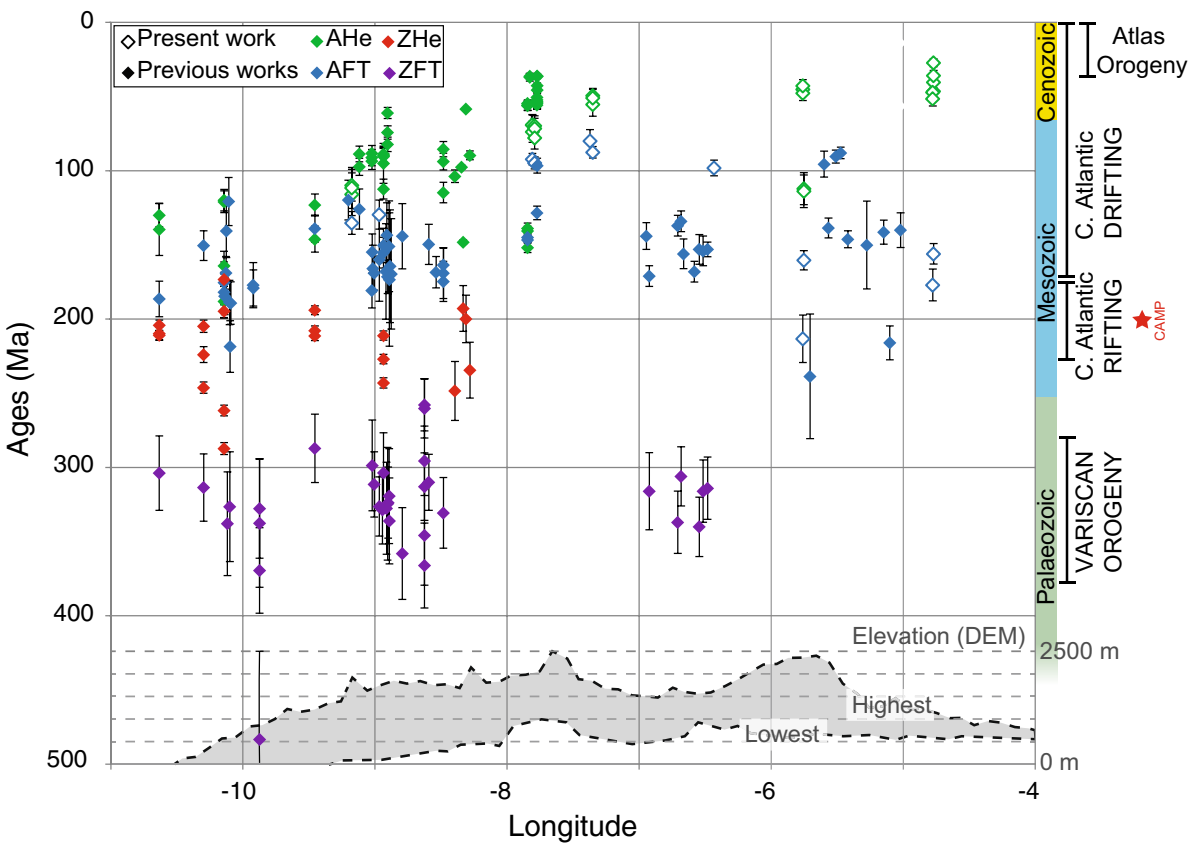

(a) Western inliers

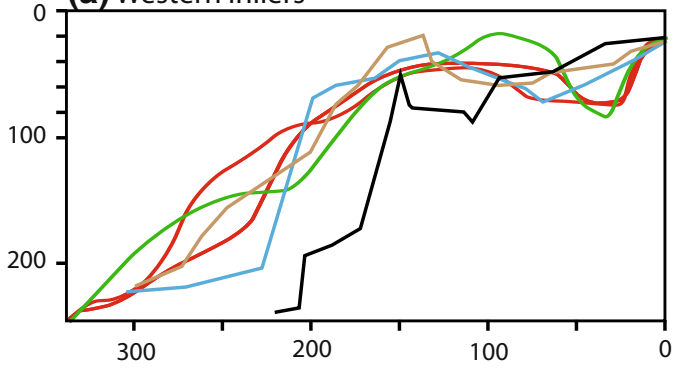

Present work - Kerdous inlier (Mor210-06) Ruiz et al. (2001) - Kerdous inlier

Ruiz et al. (2001) - Ifni inlier

Sehrt (2014) - Kerdous inlier (MA-12)

Sehrt (2014) - Kerdous inlier (MA-15)

(b) Central inliers

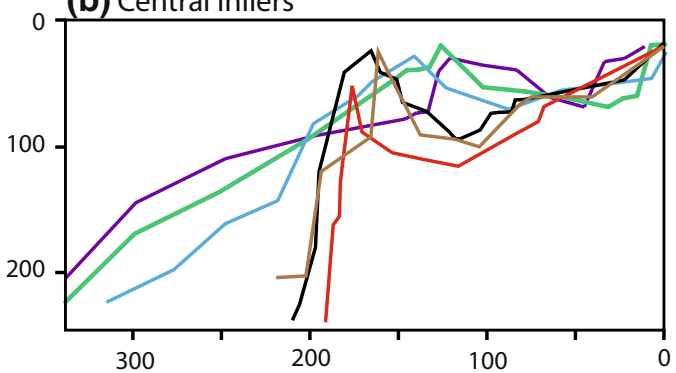

Present work - Agadir-Melloul inlier (Mor210-09) Present work - Agadir-Melloul inlier (Mor210-10) Present work - Zenaga inlier (Mor210-12) Sehrt (2014) - Irherm inlier (MA-01)

Oukassou et al. (2013) - Bou Azzer inlier (BA06) Oukassou et al. (2013) - Bou Azzer inlier (BA07)

(c) Eastern inliers

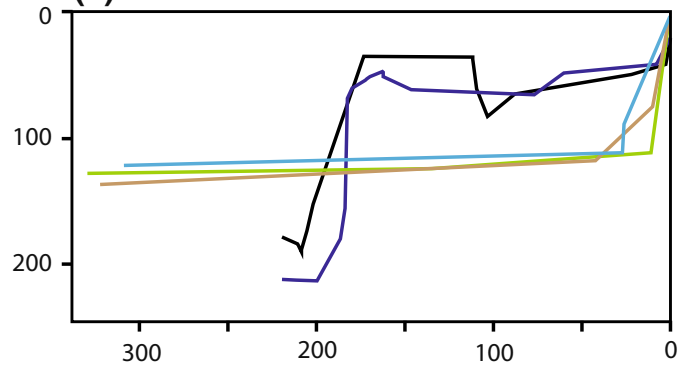

Present work - Saghro inlier (Mor210-15)

Present work - Ougnat inlier (Mor210-16)

Malusa et al. (2007) - Saghro inlier (S2)

Malusa et al. (2007) - Saghro inlier (S3)

Malusa et al. (2007) - Saghro inlier (S4) 


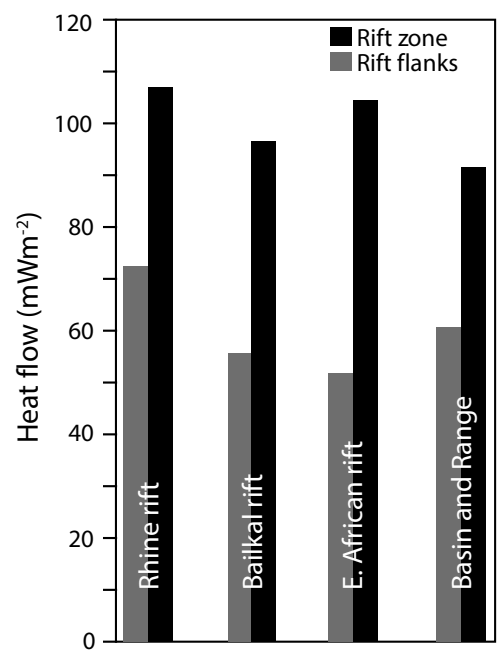

Fig. 9 Measured heat flow values in areas of active crustal rifting and their flanking domains. Modified from Kusznir and Park (1987)

(a) MOR210-06

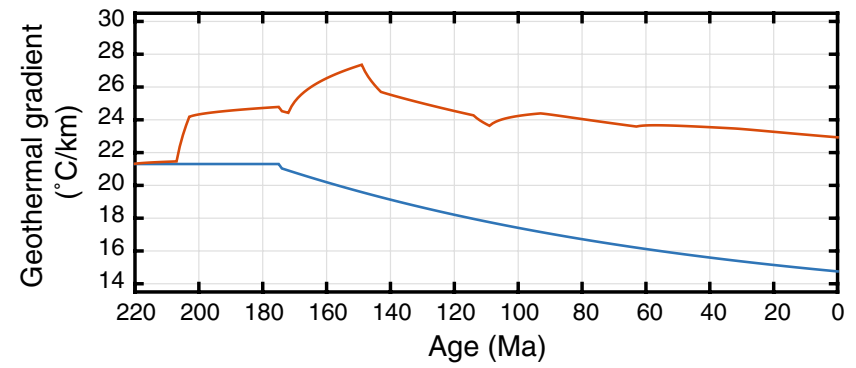

(c) MOR210-10

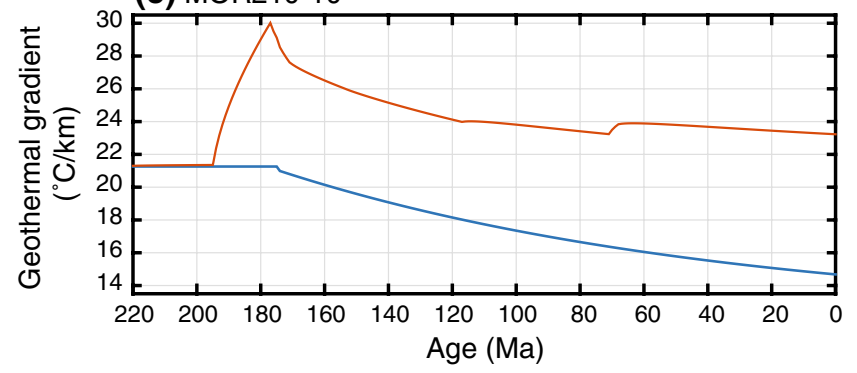

(e) MOR210-15

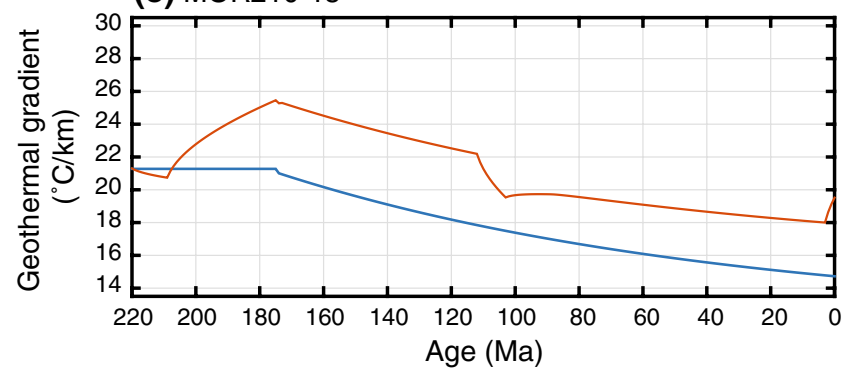

Fig. 10 Calculated variation of the geothermal gradient with time, assuming an initial heat flow of $75 \mathrm{mWm}^{-2}$. The blue line shows the geothermal gradient corrected for the heat loss due to the cooling of belt (Rimi 1990, 1999). The initial geothermal gradient is calculated using Eqs. (1) and (2), according to Ehlers (2005):

$T(z)=T_{0}+\frac{q_{0}}{k} z-\frac{A z^{2}}{2 k}$

where $T(z)$ is temperature as function of depth $(z), T_{0}$ $\left(20{ }^{\circ} \mathrm{C}\right)$ and $q_{0}$ are the temperature and heat flow at the Earth's surface, respectively, $k$ is the average thermal conductivity of the crust $\left(3 \mathrm{Wm}^{-1} \mathrm{~K}^{-1}\right)$.

$A(z)=A_{0} e^{\frac{-z}{D}}$

where $A_{0}\left(=2 \mu \mathrm{Wm}^{-3}\right)$ is the surface heat generation, $z$ is depth, and $D(=10 \mathrm{~km})$ is the characteristic depth over which heat producing elements are distributed.

The initial geothermal gradient is then corrected for (i) the heat loss with time ( $t$ [Myr] $)$ according to the empirical Eq. (3) derived from England and Richardson (1980),

(b) MOR210-09

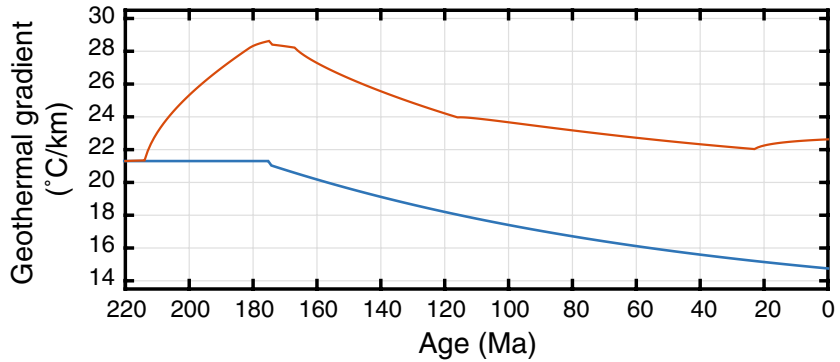

(d) MOR210-12

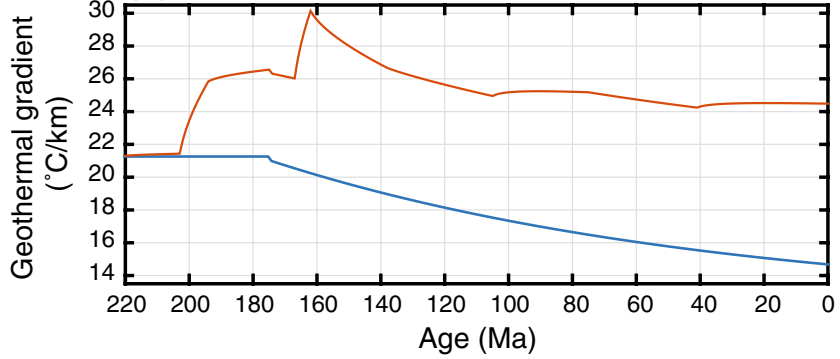

(f) MOR210-16

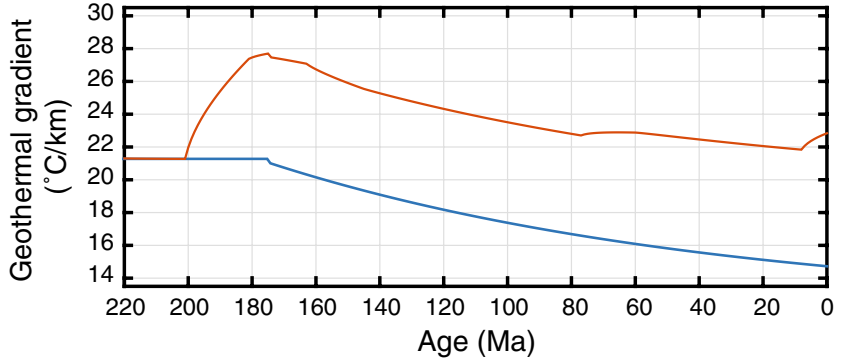

the lithosphere. The red line shows the geothermal gradient corrected for heat loss and the effect of sedimentation and erosion 

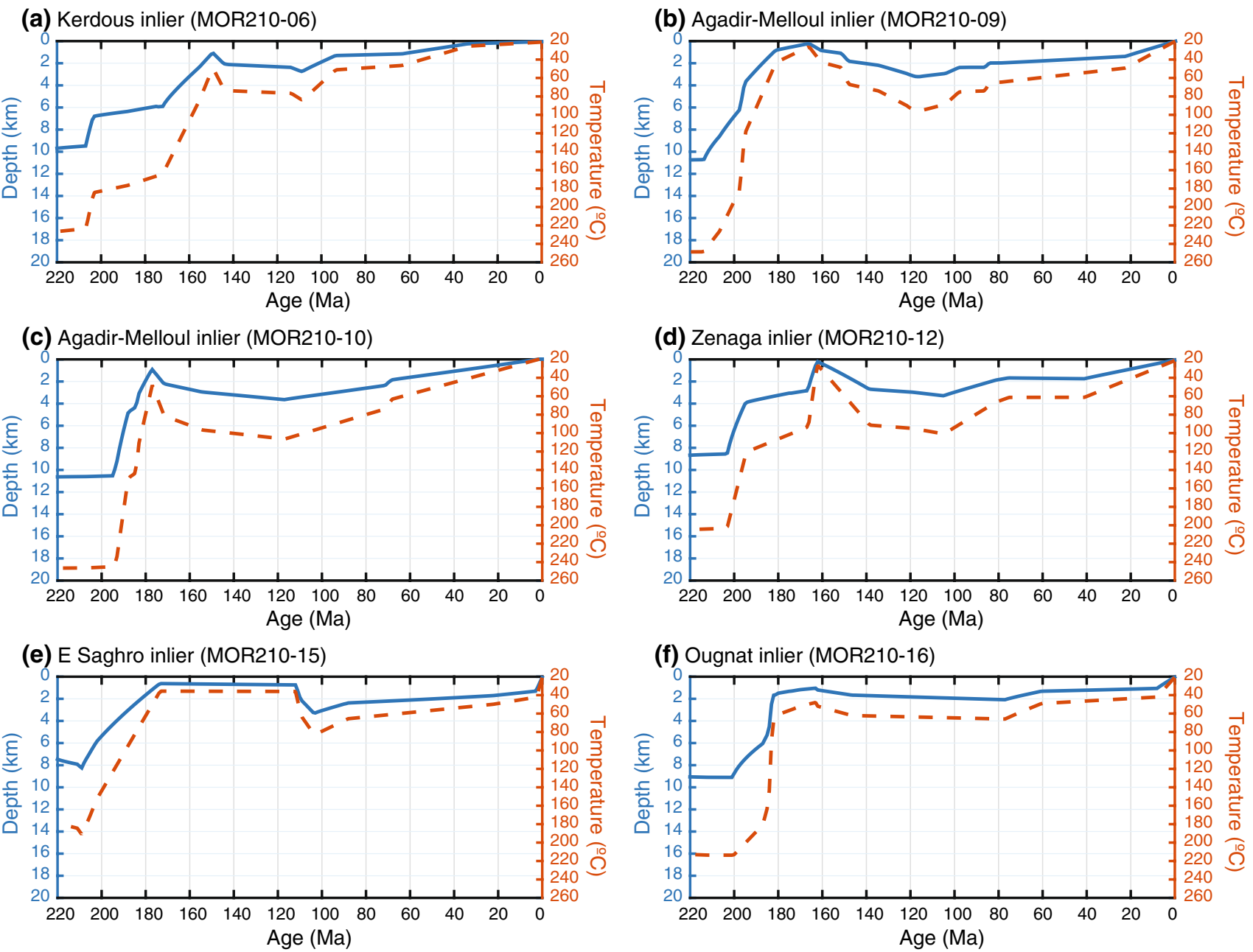

Fig. 11 Time-depth $(t-D)$ paths for each of the modeled samples, obtained by converting the best-fit $t-T$ paths (Fig. 6) using the corrected geothermal gradients (Fig. 10). The $t-D$ paths are shown in blue, while the $t-T$ paths are shown in red

and (ii) the effect of erosion and sedimentation according to Eq. (4) from Ehlers (2005).

$q_{0}(t)=43.43 \mathrm{e}^{-7.210^{-3} t}+44 \mathrm{e}^{-5.710^{-5} t}$

where $q_{0}(t)$ is surface heat flow as function of time $(t)$.

$$
\begin{aligned}
T(z, t)= & T_{0}+\Gamma_{b}(z-v t)+\frac{1}{2} \Gamma_{b} \\
& \times\left[(z+v t) \exp \left(\frac{v z}{\alpha}\right) \operatorname{erfc}\left(\frac{z+v t}{2(\alpha t)^{\frac{1}{2}}}\right)\right. \\
& \left.-(z-v t) \operatorname{erfc}\left(\frac{z-v t}{2(\alpha t)^{\frac{1}{2}}}\right)\right]
\end{aligned}
$$

where $\Gamma_{b}$ is the initial geothermal gradient, erfc is the complementary error function, $v$ is the sedimentation or erosion rate, and $\alpha$ is the thermal diffusivity.
The calculated geothermal gradients (Fig. 10) were then used to convert the modeled $t-T$ paths to burial history (Fig. 11).

\section{Burial history and tectonic evolution of the Anti-Atlas}

\section{Paleozoic evolution}

The Paleozoic evolution of the Anti-Atlas domain as described in the literature was characterized by a strong subsidence and deposition of thick clastic sedimentary sequences between the Cambrian and the Carboniferous (Helg et al. 2004; Burkhard et al. 2006; Soulaimani and Burkhard 2008; Michard et al. 2010; Soulaimani et al. 2014). The subsidence was first controlled by crustal extension that started in the Late Proterozoic and lasted until the Early Cambrian. Then thermal subsidence with little evidence of tectonic activity took place from the Middle Cambrian to the Middle 
Carboniferous. This is in agreement with ZFT ages obtained on samples from the western and central Anti-Atlas, which indicate that the currently exposed basement rocks were at temperatures around $300-240{ }^{\circ} \mathrm{C}$ between 350 and $280 \mathrm{Ma}$ (Fig. 7) (Sebti et al. 2009; Oukassou et al. 2013; Sehrt 2014).

During the Carboniferous-Permian, the Variscan orogeny driven by the continental collision of Laurasia and Gondwana resulted in inversion, folding, and exhumation of the Precambrian-Paleozoic basement of the Anti-Atlas domain (Fig. 12a) (Burkhard et al. 2006; Soulaimani and Burkhard 2008). Deformation was controlled by thick-skinned inversion of the basement with minimum estimates of shortening on the order of 15-25 km and topography in excess of $10 \mathrm{~km}$ (Burkhard et al. 2006). However, thermal modeling constraint by AFT data from the Bou Azzer inlier in the central Anti-Atlas indicates only $5 \mathrm{~km}$ of exhumation during the Carboniferous-Permian time interval (Oukassou et al. 2013).

\section{Mesozoic to Cenozoic evolution}

The Mesozoic to Cenozoic evolution of the Anti-Atlas as described by our thermal modeling (Fig. 6) and the inferred burial history (Fig. 11) reveals the existence of major tectonic events (Fig. 12b-d). The entire Anti-Atlas belt appears to be affected by two episodes of exhumation separated by an episode of subsidence (Fig. 11).

\section{Late Triassic to Jurassic exhumation}

The first event occurred in the Late Triassic and led to the exhumation and erosion of 7.5-10.5 km of crustal rocks by the end of the Middle Jurassic (ca. 160-150 Ma). The exhumation could have initiated earlier than the Late Triassic as our modeling only covered the post-Variscan time interval (220-0 Ma).

During early Mesozoic times, the Anti-Atlas domain was flanked by domains experiencing major lithospheric stretching and thinning (Fig. 12b). These are the Atlantic rift to the west, which was active from the Late Triassic (ca. $228 \mathrm{Ma}$ ) until the Early Jurassic (ca. $175 \mathrm{Ma}$ ) (Klitgord and Schouten 1986; Favre and Stampfli 1992; Davison 2005), and the Atlas rift to the north, which formed the southern branch of the Tethys rift between the Triassic and the Middle Jurassic (ca. $161 \mathrm{Ma}$ ) (Guiraud 1998; Frizon de Lamotte et al. 2000; El Harfi et al. 2006). Given the location of the Anti-Atlas domain, the initial exhumation event, which is contemporaneous with continental rifting in the Central Atlantic and the Tethyan High Atlas trough, could be rift shoulder uplift driven by the strong necking of the lithosphere underneath the two rift systems (Fig. 12b).

\section{Jurassic to Early Cretaceous subsidence}

The exhumation that ended by $180-175 \mathrm{Ma}$ in the AgadirMelloul, E Saghro and Ougnat inliers, and by $160-150 \mathrm{Ma}$ in the Kerdous and Zenaga inliers, was followed by 1-3 km of basement subsidence during the Late Jurassic and most of the Early Cretaceous (Fig. 11). This burial event was more pronounced in the central part of the belt (Agadir-Melloul, Zenaga, and E Saghro inliers), which experienced up to $4 \mathrm{~km}$ of subsidence (Fig. 11b-e), than the western and eastern domains (Kerdous and Ougnat inlier, respectively) where barely $1 \mathrm{~km}$ of subsidence is recorded (Fig. 11a, f). The subsidence of the Anti-Atlas basement was coeval with the early post-rift phase of the Central Atlantic and the High Atlas-Tethys (Fig. 12c). That is a period of thermal relaxation of the lithosphere and subsequent thermal subsidence which probably affected the Anti-Atlas crust as well. The increase in subsidence toward the central domain of the Anti-Atlas mimics the evolution of the High Atlas trough, which Mesozoic depocenter was located in the central part of the rift system (Ellouz et al. 2003; Barbero et al. 2007; Gouiza et al. 2010).

\section{Late Cretaceous-Cenozoic exhumation}

The basement rocks were then slowly brought to the surface after experiencing 2-3.5 km of exhumation throughout the Late Cretaceous and the Cenozoic. The renewal of exhumation in the Anti-Atlas started in the Aptian-Albian time (ca. 120-100), which coincides with the timing of continental break-up in both the South and North Atlantics (Macdonald et al. 2003; Tucholke et al. 2007). The resulting changes in plate tectonic motion initiated the convergence between Africa and Iberia which caused compressive stresses in many regions of Iberia (Brede et al. 1992) and probably in Morocco as well (Gouiza 2011; Bertotti and Gouiza 2012). These intraplate stresses localized in the crust of the western Anti-Atlas and triggered the last exhumation event in the Early-Late Cretaceous (Fig. 11). The latter was enhanced during the Late Eocene-Neogene collision between Africa and Iberia/Europe (Fig. 11) and led the basement rocks of the Anti-Atlas to exhume to their present-day elevation (Fig. 12d). These compressional stresses probably reactivated the old Precambrian-Paleozoic structures in thick-skinned fashion (Helg et al. 2004) and led to the final crustal topography and thickening that we observe nowadays in the Anti-Atlas belt (Fullea et al. 2010).

\section{Uncertainties}

The absence of Mesozoic sediments nearby the sampled basement rocks in particular and along the Anti-Atlas belt in general introduces some uncertainty about the constraints used in the thermal modeling presented in this work, especially box B. However, the use of AFT and AHe 


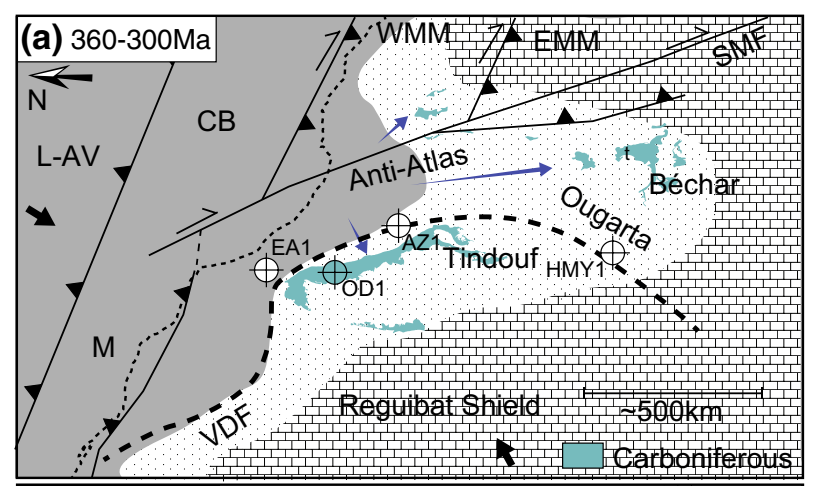

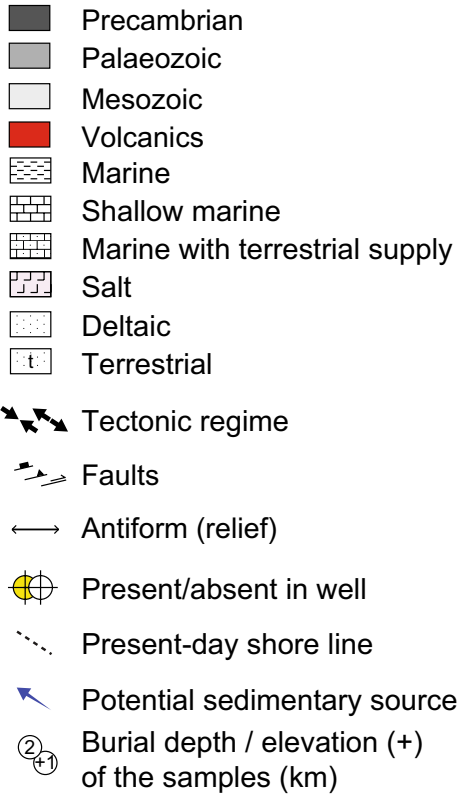
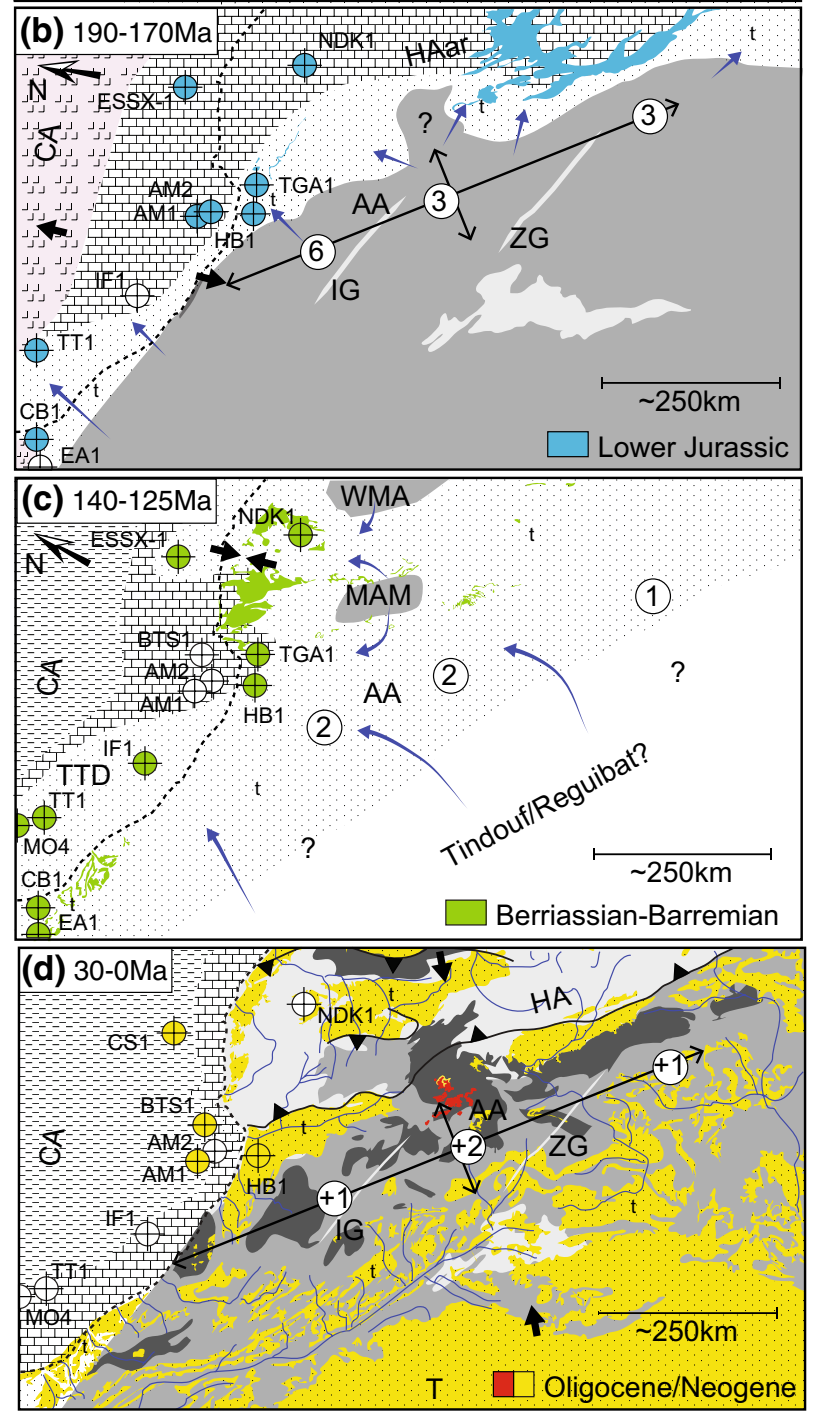

Fig. 12 Paleogeographic reconstructions of the Anti-Atlas domain during different key times of its evolution. Starting from a the Variscan Orogeny time by the end of the Paleozoic, b the Early Jurassic syn-rift and $\mathbf{c}$ the Early Cretaceous post-rift of the Central Atlantic and Tethys Oceans, and ending by $\mathbf{d}$ the Neogene-present times. See Table 5 for references used to constrain the different paleogeographic reconstructions. $A A$ Anti-Atlas, $B$ Bechar, $C A$ Central Atlantic Ocean,
$C A r$ Central Atlantic rift, $C B$ coastal block, $H A$ High Atlas, HAar High Atlas aborted rift, $H A r$ High Atlas rift, IG/ZG Ighern/Zguid CAMP related dykes, $J B$ Jebilets, $L-A V$ Laurentia-Avalonia, $O G$ Ougarta, SMF Sub-Meseta Fault, $T$ Tindouf, TTD Tan-Tan Delta, TTF Tizi n' Test Fault, $V D F$ Variscan deformation front, WAC West African Craton, WMA Western Moroccan Arch, WMM/EMM Western/ Eastern Moroccan Meseta 
(a) Kerdous inlier (MOR210-06)

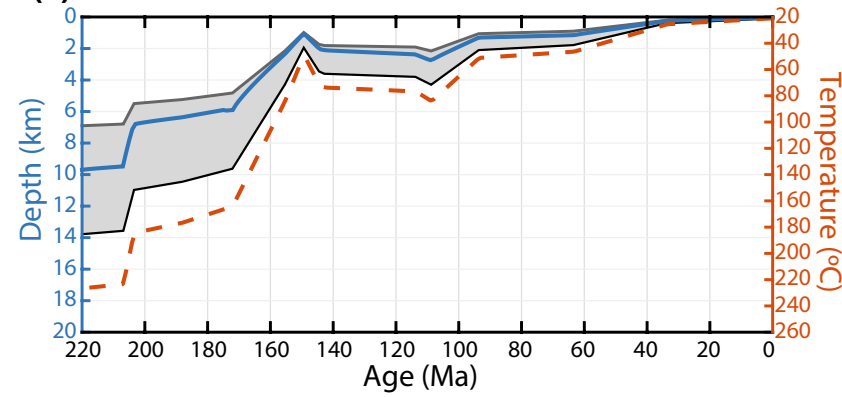

(c) Agadir-Melloul inlier (MOR210-10)

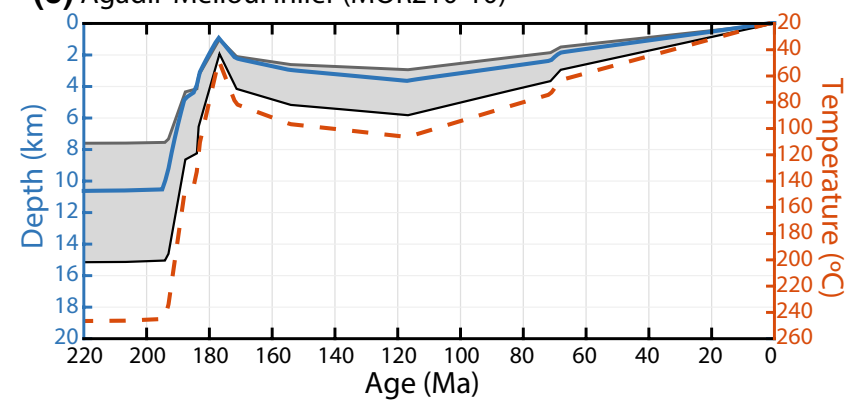

(e) E Saghro inlier (MOR210-15)

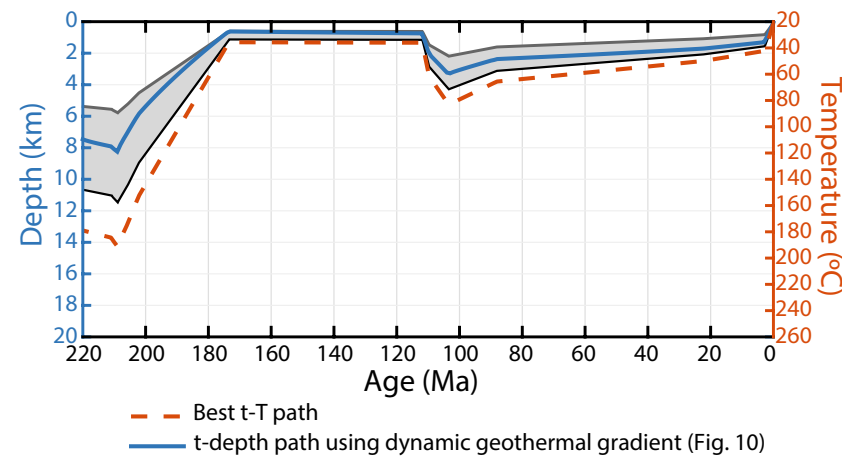

(b) Agadir-Melloul inlier (MOR210-09)

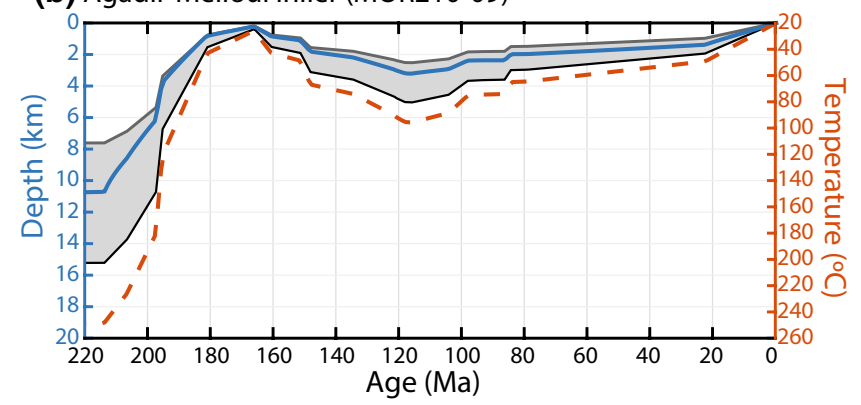

(d) Zenaga inlier (MOR210-12)

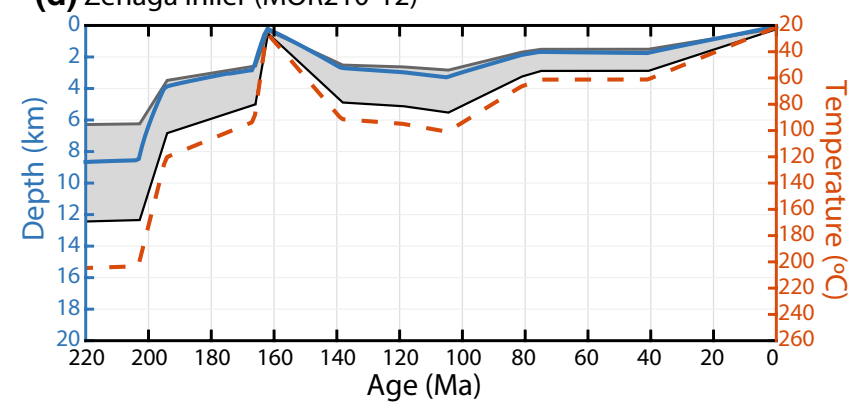

(f) Ougnat inlier (MOR210-16)

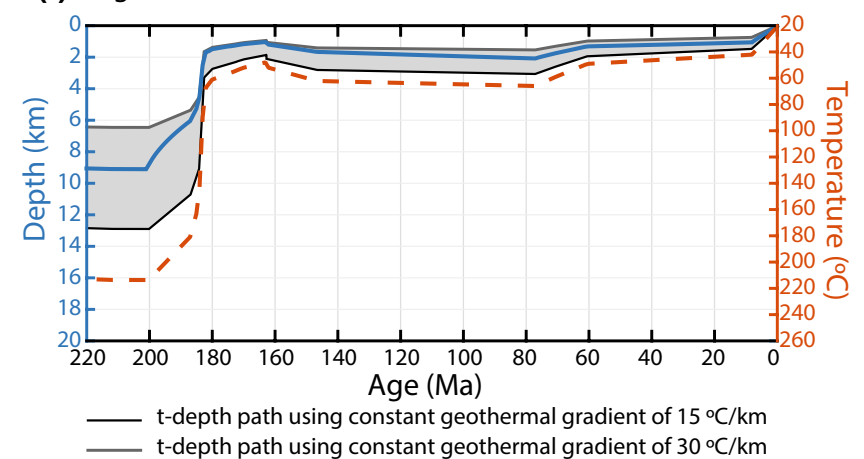

Fig. 13 Best-fit $t-T$ paths (dashed red lines) with corresponding burial histories ( $t$-depth) inferred using the dynamic geothermal gradient from Fig. 10 (blue line) and constant geothermal gradients of $15^{\circ} \mathrm{C} / \mathrm{km}$ (black line) and $30^{\circ} \mathrm{C} / \mathrm{km}$ (gray line)

data simultaneously helps to better constrain the modeling and increases the robustness of the obtained $t-T$ paths. This is confirmed by the various good $t-T$ paths which cluster around the best $t-T$ path in each of the models (Fig. 6).

Another source of uncertainty is the geothermal gradient which is used to estimate the amounts of exhumation and subsidence. Adopting a dynamic geothermal gradient (Fig. 10), which is sensitive to the thermal state of the lithosphere, subsidence and erosion, is geologically more realistic, although it relies on parameters that evolve with time and are difficult to constrain (e.g., initial heat flow). In Fig. 13, we compare burial histories which were obtained using the dynamic geothermal gradient (Fig. 10) and two end-member geothermal gradients of 15 and $30{ }^{\circ} \mathrm{C} / \mathrm{km}$, respectively. As expected, changing the geothermal gradient impacts greatly the amount of exhumation and subsidence derived from the modeled thermal history. For instance, the Late Triassic-Middle Jurassic $10.5 \mathrm{~km}$ of exhumation documented in the Agadir-Melloul inlier could increase to $15 \mathrm{~km}$ or decrease to only $7.5 \mathrm{~km}$, depending on the geothermal gradient applied (i.e., 15 or $30{ }^{\circ} \mathrm{C} / \mathrm{km}$ respectively). Although the amounts of vertical motions are highly dependent on the Earth's geotherm, the observation of kmscale exhumation and subsidence in the Anti-Atlas domain through Mesozoic and Cenozoic times remains valid.

\section{Conclusions}

The evolution of vertical movements in the Anti-Atlas belt depicted above is at odds with previous tectonic interpretations that assumed the Anti-Atlas to be stable during 


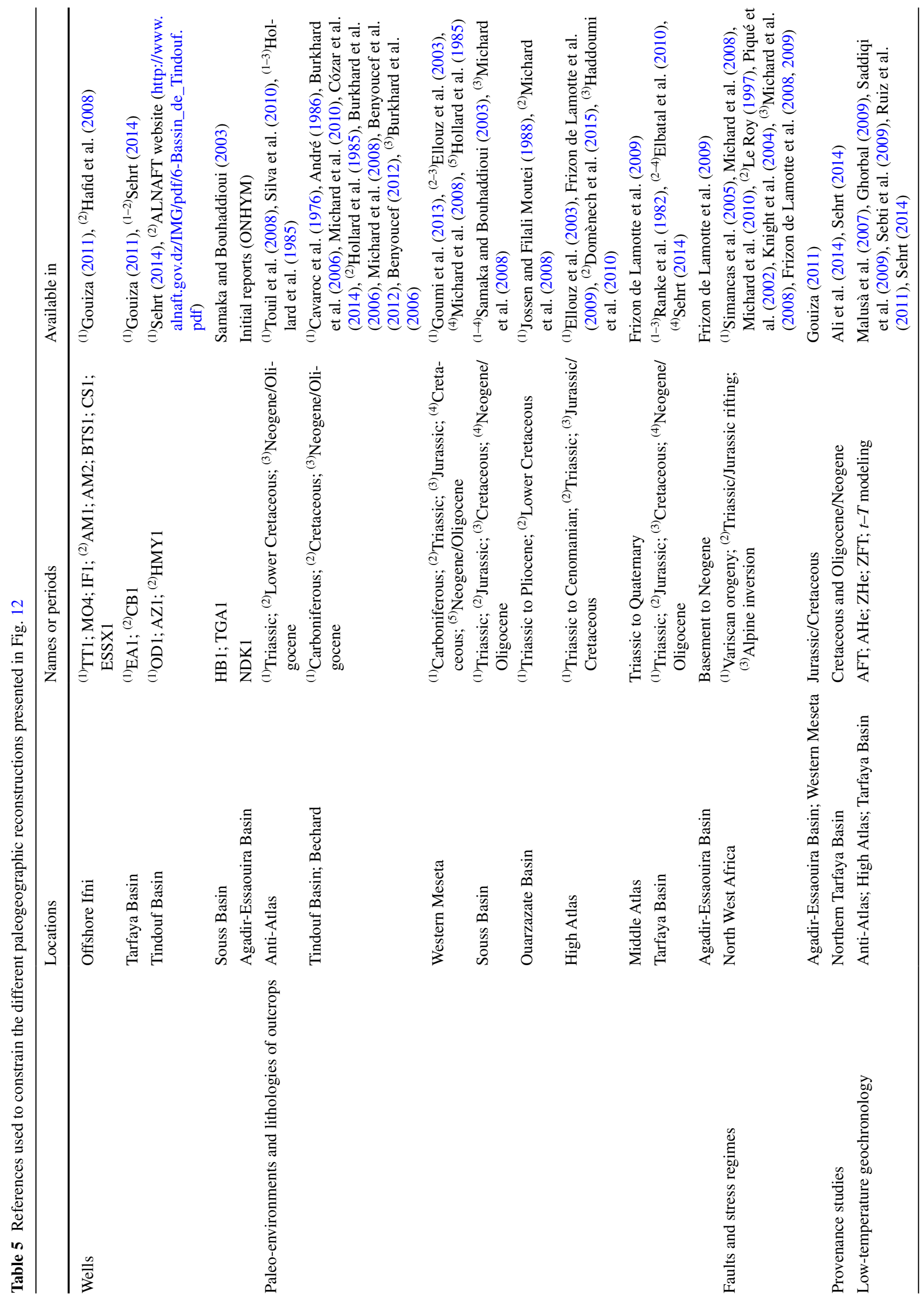


most of the Mesozoic (Choubert 1963; Michard 1976), but also with the assumption that tectonic vertical motions in rifted margins are restricted in time to the syn-rift phase. However, it is in agreement with recent studies that have revealed the existence of major tectonic vertical motions that affected large domains on the eastern margin of the Central Atlantic Ocean (Malusà et al. 2007; Ghorbal et al. 2008; Ghorbal 2009; Gouiza 2011; Ruiz et al. 2011; Bertotti and Gouiza 2012; Oukassou et al. 2013; Sehrt 2014; Leprêtre et al. 2015).

Thereby, our data and the subsequent interpretation imply that the Anti-Atlas domain experienced up to $10.5 \mathrm{~km}$ of crustal exhumation and denudation by the Middle Jurassic, in relation with continental rifting in the Central Atlantic and the Tethyan Atlas. The early post-rift period in both rift systems was driven by lithospheric cooling and crustal subsidence and extended to the Anti-Atlas domain which basement rocks record $1-3 \mathrm{~km}$ of subsidence during the Late Jurassic and the Early Cretaceous. The final exhumation of the Anti-Atlas belt started by the end of the Early Cretaceous (ca. Aptian-Albian) and was coeval with, and probably driven by, changes in plate motions and, ultimately, the collision between Africa and Iberia/Europe.

Open Access This article is distributed under the terms of the Creative Commons Attribution 4.0 International License (http://creativecommons.org/licenses/by/4.0/), which permits unrestricted use, distribution, and reproduction in any medium, provided you give appropriate credit to the original author(s) and the source, provide a link to the Creative Commons license, and indicate if changes were made.

\section{References}

Aarab EM, Rahimi A, Rocci G (1994) Un exemple de différenciation transverse: le Grand Dyke de Foum Zguid (Anti-Atlas, Maroc). C R Acad Sci Sér 2 319:209-215

Ali S, Stattegger K, Garbe-Schönberg D et al (2014) The provenance of Cretaceous to Quaternary sediments in the Tarfaya basin, SW Morocco: evidence from trace element geochemistry and radiogenic Nd-Sr isotopes. J Afr Earth Sci 90:64-76. doi:10.1016/j. jafrearsci.2013.11.010

André JP (1986) Bioconstruction carbonatée et faciès associés du Koudiat Lahmara, Jebilet orientales (Maroc Hercynien): un épisode récifal au Viséen supérieur. Eclogae Geologicae Helvetica 79:1-25. doi:10.5169/seals-165836

Baidder L, Raddi Y, Tahiri M, Michard A (2008) Devonian extension of the Pan-African crust north of the West African craton, and its bearing on the Variscan foreland deformation: evidence from eastern Anti-Atlas (Morocco). In: Geological Society, London, Special Publications, pp 453-465

Barbero L, Teixell A, Arboleya M et al (2007) Jurassic-to-present thermal history of the central High Atlas (Morocco) assessed by low-temperature thermochronology. Terra Nova 19:58-64. doi:10.1111/j.1365-3121.2006.00715.x

Beauchamp J (1988) Triassic sedimentation and rifting in the $\{\mathrm{H}\}$ igh $\{$ A $\}$ tlas ( $\{\mathrm{M}\}$ orocco). In: Manspeizer W (ed) Triassic-Jurassic rifting: continental breakup and the origin of the atlantic ocean and passive margins. Elsevier, New York, pp 477-497
Beauchamp W, Allmendinger RW, Barazangi M et al (1999) Inversion tectonics and the evolution of the High Atlas Mountains, Morocco, based on a geological-geophysical transect. Tectonics 18:163-184. doi:10.1029/1998TC900015

Benssaou M, Hamoumi N (2003) Le graben de l'Anti-Atlas occidental (Maroc): contrôle tectonique de la paléogéographie et des séquences au Cambrien inférieur. C R Geosci 335:297-305. doi:10.1016/S1631-0713(03)00033-6

Benyoucef M (2012) Le Bassin Crétacé Du Guir (Sud-Ouest Algerien): Caracterisations Litho-Biostratigraphiques, Sedimentologiques \& Paleogeographiques. Ph.D Thesis, Université de Tlemcen

Benyoucef M, Meister C, Bensalah M, Malti FZ (2012) La plateforme préafricaine (Cénomanien supérieur - Turonien inférieur) dans la région de Béchar (Algérie): stratigraphie, paléoenvironnements et signification paléobiogéographique. Revue de Paléobiologie 31:205-218

Berrahma M, Delaloye M (1989) Données géochronologiques nouvelles sur le massif volcanique du Siroua (AntiAtlas, Maroc). J Afr Earth Sci Middle East 9:651-656. doi:10.1016/0899-5362(89)90049-3

Berrahma M, Delaloye M, Faure-Muret A, Rachdi HEN (1993) Premières données géochronologiques sur le volcanisme alcalin du Jbel Saghro, Anti-Atlas, Maroc. J Afr Earth Sci Middle East 17:333-341. doi:10.1016/0899-5362(93)90077-4

Bertotti G, Gouiza M (2012) Post-rift vertical movements and horizontal deformations in the eastern margin of the Central Atlantic: middle Jurassic to Early Cretaceous evolution of Morocco. Int J Earth Sci 101:2151-2165. doi:10.1007/ s00531-012-0773-4

Bonow JM, Japsen P, Lidmar-Bergström K et al (2006) Cenozoic uplift of Nuussuaq and Disko, West Greenland-elevated erosion surfaces as uplift markers of a passive margin. Geomorphology 80:325-337. doi:10.1016/j.geomorph.2006.03.006

Bonow JM, Japsen P, Green PF et al (2009) Post-rift landscape development of north-east Brazil. Geol Surv Den Greenl Bull 17:81-84

Brandon MT, Roden-Tice MK, Garver JI (1998) Late Cenozoic exhumation of the Cascadia accretionary wedge in the Olympic Mountains, northwest Washington State. Geol Soc Am Bull 110:985-1009. doi:10.1130/0016-7606(1998)110<0985:LCEO $\mathrm{TC}>2.3 . \mathrm{CO} ; 2$

Brede DR, Hauptmann DM, Herbig P-DDH-G (1992) Plate tectonics and intracratonic mountain ranges in Morocco-the mesozoic-cenozoic development of the Central High Atlas and the Middle Atlas. Geol Rundsch 81:127-141. doi:10.1007/ BF01764544

Burkhard M, Caritg S, Helg U et al (2006) Tectonics of the AntiAtlas of Morocco. C R Geosci 338:11-24. doi:10.1016/j. crte.2005.11.012

Cavaroc VV, Padgett G, Stephens DG et al (1976) Late Paleozoic of the Tindouf Basin; North Africa. J Sediment Res 46:77-88. doi:10.1306/212F6EC4-2B24-11D7-8648000102C1865D

Chalmers JA, Pulvertaft TCR, Marcussen C, Pedersen AK (1999) New insight into the structure of the Nuussuaq Basin, central West Greenland. Mar Pet Geol 16(197-211):213-224. doi:10.1016/S0264-8172(98)00077-4

Choubert G (1947) GEOLOGIE-LACCIDENT MAJEUR DE LANTI-ATLAS. C R Hebd Seances Acad Sci 224:1172-1173

Choubert G (1963) Histoire géologique du Pécambrien de l'AntiAtlas. Notes et Mémoires du Service Géologique. Rabat, Morocco

Cózar P, García-Frank A, Somerville ID et al (2014) Lithofacies and biostratigraphical correlation of marine Carboniferous rocks in the Tindouf Basin, NW Africa. Facies 60:941-962. doi:10.1007/ s10347-014-0409-1 
D'Lemos RS, Inglis JD, Samson SD (2006) A newly discovered orogenic event in Morocco: neoproterozic ages for supposed Eburnean basement of the Bou Azzer inlier, Anti-Atlas Mountains. Precambrian Res 147:65-78. doi:10.1016/j. precamres.2006.02.003

Davison I (2005) Central Atlantic margin basins of North West Africa: geology and hydrocarbon potential (Morocco to Guinea). J Afr Earth Sci 43:254-274. doi:10.1016/j.jafrearsci.2005.07.018

Dewey JF, Kidd WSF (1974) Continental collisions in the appalachian-caledonian orogenic belt: variations related to complete and incomplete suturing. Geology 2:543-546. doi:10.1130/0091-7613(1974)2<543:CCITAO>2.0.CO;2

Domènech M, Teixell A, Babault J, Arboleya M-L (2015) The inverted Triassic rift of the Marrakech High Atlas: a reappraisal of basin geometries and faulting histories. Tectonophysics 663:177-191. doi:10.1016/j.tecto.2015.03.017

Donelick RA, Ketcham RA, Carlson WD (1999) Variability of apatite fission-track annealing kinetics: II. Crystallographic orientation effects. Am Mineral 84:1224-1234

Dumitru TA (1993) A new computer-automated microscope stage system for fission-track analysis. Nucl Tracks Radiat Meas 21:575-580. doi:10.1016/1359-0189(93)90198-I

Dunkl I (2002) Trackkey: a Windows program for calculation and graphical presentation of fission track data. Comput Geosci 28:3-12. doi:10.1016/S0098-3004(01)00024-3

Ehlers TA (2005) Crustal thermal processes and the interpretation of thermochronometer data. Rev Mineral Geochem 58:315-350. doi:10.2138/rmg.2005.58.12

Elbatal Y, Aadjour M, Saber N et al (2010) Étude sismo-structurale du bassin de Tarfaya-Boujdour Onshore. Afr Sci 6:49-59

El Hadi H, Simancas JF, Martínez-Poyatos D et al (2010) Structural and geochronological constraints on the evolution of the Bou Azzer Neoproterozoic ophiolite (Anti-Atlas, Morocco). Precambrian Res 182:1-14. doi:10.1016/j.precamres.2010.06.011

El Harfi A, Guiraud M, Lang J (2006) Deep-rooted "thick skinned" model for the High Atlas Mountains (Morocco). Implications for the structural inheritance of the southern Tethys passive margin. J Struct Geol 28:1958-1976. doi:10.1016/j.jsg.2006.08.011

Ellouz N, Patriat M, Gaulier J-M et al (2003) From rifting to Alpine inversion: Mesozoic and Cenozoic subsidence history of some Moroccan basins. Sediment Geol 156:185-212. doi:10.1016/ S0037-0738(02)00288-9

England PC, Richardson SW (1980) Erosion and the age dependence of continental heat flow. Geophys J Int 62:421-437. doi:10.1111/j.1365-246X.1980.tb04865.X

Ennih N, Liégeois J-P (2001) The Moroccan Anti-Atlas: the West African craton passive margin with limited Pan-African activity. Implications for the northern limit of the craton. Precambrian Res 112:289-302

Ennih N, Liégeois J-P (2008) The boundaries of the West African craton, with special reference to the basement of the Moroccan metacratonic Anti-Atlas belt. Geol Soc Lond Spec Publ 297:117. doi: $10.1144 /$ SP297.1

Farley KA (2000) Helium diffusion from apatite: general behavior as illustrated by Durango fluorapatite. J Geophys Res Solid Earth 105:2903-2914. doi:10.1029/1999JB900348

Favre P, Stampfli GM (1992) From rifting to passive margin: the examples of the Red Sea, Central Atlantic and Alpine Tethys. Tectonophysics 215:69-97. doi:10.1016/0040-1951(92)90075-H

Frizon de Lamotte D, Bezar BS, Bracène R, Mercier E (2000) The two main steps of the Atlas building and geodynamics of the western Mediterranean. Tectonics 19:740-761. doi:10.1029/20 00TC900003

Frizon de Lamotte D, Zizi M, Missenard Y et al (2008) The atlas system. In: Michard A, Saddiqi O, Chalouan A,
Frizon de Lamotte D (eds) Continental evolution: the geology of Morocco. Springer, Berlin, Heidelberg

Frizon De Lamotte D, Leturmy P, Missenard Y et al (2009) Mesozoic and Cenozoic vertical movements in the Atlas system (Algeria, Morocco, Tunisia): an overview. Tectonophysics 475:9-28. doi:10.1016/j.tecto.2008.10.024

Fullea J, Fernàndez M, Afonso JC et al (2010) The structure and evolution of the lithosphere-asthenosphere boundary beneath the Atlantic-Mediterranean Transition Region. Lithos 120:74-95. doi:10.1016/j.lithos.2010.03.003

Gasquet D, Ennih N, Liégeois J-P et al (2008) The Pan-African Belt. In: Michard A, Saddiqi O, Chalouan A, de Lamotte DF (eds) Continental evolution: the geology of Morocco. Springer, Berlin

Ghorbal B (2009) Mesozoic to quaternary thermo-tectonic evolution of Morocco (NW Africa). Ph.D Thesis, Vrije Universiteit

Ghorbal B, Bertotti G, Foeken J, Andriessen P (2008) Unexpected Jurassic to Neogene vertical movements in "stable" parts of NW Africa revealed by low temperature geochronology. Terra Nova 20:355-363. doi:10.1111/j.1365-3121.2008.00828.x

Gouiza M (2011) Mesozoic source-to-sink systems in NW Africa: geology of vertical movements during the birth and growth of the Moroccan rifted margin. Vrije Universiteit Amsterdam, Amsterdam

Gouiza M, Bertotti G, Hafid M, Cloetingh S (2010) Kinematic and thermal evolution of the Moroccan rifted continental margin: Doukkala-High Atlas transect. Tectonics 29(22):2010. doi:10.1 029/2009TC002464

Goumi NE, Jaffal M, Rolf C et al (2013) Rock magnetic study of basic intrusions and massive sulphides in the Hercynian central Jebilets Massif (Occidental-Meseta), Morocco. Arab J Geosci 6:2581-2597. doi:10.1007/s12517-012-0547-0

Green PF, Duddy IR, Laslett GM et al (1989) Thermal annealing of fission tracks in apatite 4. Quantitative modelling techniques and extension to geological timescales. Chem Geol Isot Geosci Sect 79:155-182. doi:10.1016/0168-9622(89)90018-3

Grist AM, Zentilli M (2003) Post-Paleocene cooling in the southern Canadian Atlantic region: evidence from apatite fission track models. Can J Earth Sci 40:1279-1297

Guiraud R (1998) Mesozoic rifting and basin inversion along the northern African Tethyan margin: an overview. Geol Soc Lond Spec Publ 132:217-229. doi:10.1144/GSL.SP.1998.132.01.13

Guiraud R, Bellion Y, Benkhelil J, Moreau C (1987) Post-Hercynian tectonics in Northern and Western Africa. Geol J 22:433-466. doi:10.1002/gj.3350220628

Guiraud R, Bosworth W, Thierry J, Delplanque A (2005) Phanerozoic geological evolution of Northern and Central Africa: an overview. J Afr Earth Sci 43:83-143. doi:10.1016/j. jafrearsci.2005.07.017

Haddoumi H, Charrière A, Mojon P-O (2010) Stratigraphie et sédimentologie des «Couches rouges» continentales du Jurassique-Crétacé du Haut Atlas central (Maroc): implications paléogéographiques et géodynamiques. Geobios 43:433-451. doi:10.1016/j.geobios.2010.01.001

Hafid M, Tari G, Bouhadioui D et al (2008) Atlantic Basins. In: Michard A, Saddiqi O, Chalouan A, Frizon de Lamotte D (eds) Continental evolution: the geology of Morocco. Springer, Berlin, Heidelberg

Harman R, Gallagher K, Brown R et al (1998) Accelerated denudation and tectonic/geomorphic reactivation of the cratons of northeastern Brazil during the Late Cretaceous. J Geophys Res 103:27091-27105. doi:10.1029/98JB02524

Hefferan K, Soulaimani A, Samson SD et al (2014) A reconsideration of Pan African orogenic cycle in the Anti-Atlas Mountains, Morocco. J Afr Earth Sci 98:34-46. doi:10.1016/j. jafrearsci.2014.03.007 
Helg U, Burkhard M, Caritg S, Robert-Charrue C (2004) Folding and inversion tectonics in the Anti-Atlas of Morocco. Tectonics 23:TC4006. doi:10.1029/2003TC001576

Hollard H, Choubert G, Bronner G et al (1985) Carte géologique du Maroc, scale 1: 1,000,000. Service de cartes géologiques du Maroc, Rabat

Hurford AJ, Green PF (1983) The zeta age calibration of fission-track dating. Chem Geol 41:285-317. doi:10.1016/ S0009-2541(83)80026-6

Japsen P, Bonow JM, Green PF et al (2006) Elevated, passive continental margins: long-term highs or Neogene uplifts? New evidence from West Greenland. Earth Planet Sci Lett 248:330 339. doi:10.1016/j.eps1.2006.05.036

Jelinek AR, Chemale F Jr, van der Beek PA et al (2014) Denudation history and landscape evolution of the northern East-Brazilian continental margin from apatite fission-track thermochronology. J South Am Earth Sci 54:158-181. doi:10.1016/j. jsames.2014.06.001

Jossen J, Filali Moutei J (1988) Bassin d'Ouarzazate, synthèse stratigraphique et structurale. Contribution à l'étude des aquifères profonds-Projet PNUD-DRPE (Direction de la Recherche et de la planification de l'Eau) MOR/86/004-Exploration des eaux profondes. Rapport Inédit, Rabat

Ketcham RA (2005) Forward and inverse modeling of low-temperature thermochronometry data. Rev Mineral Geochem 58:275314. doi:10.2138/rmg.2005.58.11

Ketcham RA, Carter A, Donelick RA et al (2007) Improved modeling of fission-track annealing in apatite. Am Mineral 92:799-810. doi:10.2138/am.2007.2281

Klitgord KD, Schouten H (1986) Plate kinematics of the central Atlantic. In: Vogt PR, Tucholke BE (eds) The Western North Atlantic region: the geology of North America. Geological Society of America, Boulder, USA, pp 351-378

Knight KB, Nomade S, Renne PR et al (2004) The Central Atlantic Magmatic Province at the Triassic-Jurassic boundary: paleomagnetic and 40Ar/39Ar evidence from Morocco for brief, episodic volcanism. Earth Planet Sci Lett 228:143-160. doi:10.1016/j.epsl.2004.09.022

Kröner A, Stern R (2004) Africa: Pan-African orogeny. Encyclopedia of Geology. Elsevier, Amsterdam, pp 1-12

Kusznir NJ, Park RG (1987) The extensional strength of the continental lithosphere: its dependence on geothermal gradient, and crustal composition and thickness. Geol Soc Lond Spec Publ 28:35-52. doi:10.1144/GSL.SP.1987.028.01.04

Leprêtre R, Missenard Y, Barbarand J et al (2015) Postrift history of the eastern central Atlantic passive margin: insights from the Saharan region of South Morocco. J Geophys Res Solid Earth 120:2014JB011549. doi:10.1002/2014JB011549

Le Roy P (1997) Les bassins ouest-marocains : leur formation et leur évolution dans le cadre de l'ouverture et du développement de l'Atlantique central (marge africaine). Ph.D Thesis, Université de Bretagne Occidentale

Li G, Pe-Piper G, Piper DJW (2012) The provenance of Middle Jurassic sandstones in the Scotian Basin: petrographic evidence of passive margin tectonics 1 This article is one of a series of papers published in this CJES Special Issue on the theme of Mesozoic-Cenozoic geology of the Scotian Basin. 2 Geological Survey of Canada Contribution 20110319. Can J Earth Sci 49:1463-1477. doi:10.1139/e2012-061

Linnemann U, Romer RL, Pin C et al (2008) Precambrian. In: Mccann T (ed) The Geology of Central Europe. Geological Society, London, pp 21-101

Macdonald D, Gomez-Perez I, Franzese J et al (2003) Mesozoic break-up of SW Gondwana: implications for regional hydrocarbon potential of the southern South Atlantic. Mar Pet Geol 20:287-308. doi:10.1016/S0264-8172(03)00045-X
Malusà MG, Polino R, Feroni AC et al (2007) Post-Variscan tectonics in eastern Anti-Atlas (Morocco). Terra Nova 19:481-489. doi:10.1111/j.1365-3121.2007.00775.x

Marzoli A, Bertrand H, Knight KB et al (2004) Synchrony of the Central Atlantic magmatic province and the *Triassic-Jurassic boundary climatic and biotic crisis. Geology 32:973-976. doi:10.1130/G20652.1

Michard A (1976) Elément de géologie marocaine. Sérvice géologique Maroc, Rabat

Michard A, Hoepffner C, Soulaimani A, Baidder L (2008) The variscan belt. In: Michard A, Saddiqi O, Chalouan A, Frizon de Lamotte D (eds) Continental evolution: the geology of Morocco. Springer, Berlin, Heidelberg

Michard A, Soulaimani A, Hoepffner C et al (2010) The South-Western Branch of the Variscan Belt: evidence from Morocco. Tectonophysics 492:1-24. doi:10.1016/j.tecto.2010.05.021

Nomade S, Knight KB, Beutel E et al (2007) Chronology of the Central Atlantic Magmatic Province: implications for the Central Atlantic rifting processes and the Triassic-Jurassic biotic crisis. Palaeogeogr Palaeoclimatol Palaeoecol 244:326-344. doi:10.1016/j.palaeo.2006.06.034

Oukassou M, Saddiqi O, Barbarand J et al (2013) Post-Variscan exhumation of the Central Anti-Atlas (Morocco) constrained by zircon and apatite fission-track thermochronology. Terra Nova 25:151-159. doi:10.1111/ter.12019

Pe-Piper G, MacKay RM (2006) Provenance of Lower Cretaceous sandstones onshore and offshore Nova Scotia from electron microprobe geochronology and chemical variation of detrital monazite. Bull Can Pet Geol 54:366-379

Peulvast J-P, Claudino Sales V, Bétard F, Gunnell Y (2008) Low post-Cenomanian denudation depths across the Brazilian Northeast: implications for long-term landscape evolution at a transform continental margin. Glob Planet Change 62:39-60. doi:10.1016/j.gloplacha.2007.11.005

Piqué A, Dahmani M, Jeannette D, Bahi L (1987) Permanence of structural lines in Morocco from Precambrian to Present. J Afr Earth Sci 6:247-256. doi:10.1016/0899-5362(87)90066-2

Piqué A, Tricart P, Guiraud R et al (2002) The Mesozoic-Cenozoic Atlas belt (North Africa): an overview. Geodinamica Acta 15:185-208. doi:10.1016/S0985-3111(02)01088-4

Pollack HN, Chapman DS (1977) On the regional variation of heat flow, geotherms, and lithospheric thickness. Tectonophysics 38:279-296. doi:10.1016/0040-1951(77)90215-3

Polyak B, Smirnov YB (1968) Relationship between terrestrial heat flow and the tectonics of continents. Geotectonics 4:205-213

Press WH, Teukolsky SA, Vetterling WT, Flannery BP (1996) Numerical recipes in C: the art of scientific computing, 2nd edn. Cambridge University Press, Cambridge

Price I (1981) Provenance of the Jurassic-Cretaceous flysch, Deep Sea Drilling Project sites 370 and 416. Initial Rep Deep Sea Drill Proj 50:751-757

Ranke U, Von Rad U, Wissmann G (1982) Stratigraphy, facies and tectonic development of the on-and off-shore Aaiun-Tarfaya basin-A review. In: von Rad U, Hinz K, Sarnthein M, Seibold E (eds) Geology of the Northwest African continental margin. Springer, Berlin, Germany, pp 86-105

Ravenhurst C, Donelick R, Zentilli M et al (1990) A fission track pilot study of the thermal effects of rifting on the onshore Nova Scotian margin, Canada. Int J Radiat Appl Instrum Part Nucl Tracks Radiat Meas 17:373-378. doi:10.1016/1359-0189(90)90060-B

Reiners PW, Ehlers TA, Zeitler PK (2005) Past, present, and future of thermochronology. Rev Mineral Geochem 58:1-18. doi:10.2138/rmg.2005.58.1

Rimi A (1990) Geothermal gradients and heat flow trends in Morocco. Geothermics 19:443-454. doi:10.1016/0375-6505(90)90057-I 
Rimi A (1999) Mantle heat flow and geotherms for the main geologic domains in Morocco. Int J Earth Sci 88:458-466. doi:10.1007/ s005310050278

Ruiz GMH, Sebti S, Negro F et al (2011) From central Atlantic continental rift to Neogene uplift-western Anti-Atlas (Morocco). Terra Nova 23:35-41. doi:10.1111/j.1365-3121.2010.00980.x

Saddiqi O, El Haimer F-Z, Michard A et al (2009) Apatite fissiontrack analyses on basement granites from south-western Meseta, Morocco: paleogeographic implications and interpretation of AFT age discrepancies. Tectonophysics 475:29-37. doi:10.1016/j.tecto.2009.01.007

Samaka F, Bouhaddioui D (2003) Evaluation du Potentiel Petrolier du Bassin de Souss et de l'Offshore d'Agadir. ONHYM internal report, Rabat

Sebai A, Feraud G, Bertrand H, Hanes J (1991) 40Ar/39Ar dating and geochemistry of tholeiitic magmatism related to the early opening of the Central Atlantic rift. Earth Planet Sci Lett 104:455472. doi:10.1016/0012-821X(91)90222-4

Sebti S (2011) Mouvements verticaux de l'Anti-Atlas occidental marocain (Kerdous et Ifni): Thermochronologie par traces de fission. Ph.D Thesis, University Hassan II of Casablanca

Sebti S, Saddiqi O, El Haimer FZ et al (2009) Vertical movements at the fringe of the West African Craton: first zircon fission track datings from the Anti-Atlas Precambrian basement, Morocco. C R Geosci 341:71-77. doi:10.1016/j.crte.2008.11.006

Sehrt M (2014) Variscan to Neogene long-term landscape evolution at the Moroccan passive continental margin (Tarfaya Basin and western Anti-Atlas). Ph.D Thesis, Heidelberg

Shuster DL, Flowers RM, Farley KA (2006) The influence of natural radiation damage on helium diffusion kinetics in apatite. Earth Planet Sci Lett 249:148-161. doi:10.1016/j.epsl.2006.07.028

Silva PF, Marques FO, Henry B et al (2010) Thick dyke emplacement and internal flow: a structural and magnetic fabric study of the deep-seated dolerite dyke of Foum Zguid (southern Morocco). J Geophys Res Solid Earth. doi:10.1029/2010JB007638

Simancas JF, Tahiri A, Azor A et al (2005) The tectonic frame of the Variscan-Alleghanian orogen in Southern Europe and Northern Africa. Tectonophysics 398:181-198. doi:10.1016/j. tecto.2005.02.006

Soulaimani A, Burkhard M (2008) The Anti-Atlas chain (Morocco): the southern margin of the Variscan belt along the edge of the
West African craton. Geol Soc Lond Spec Publ 297:433-452. doi:10.1144/SP297.20

Soulaimani A, Michard A, Ouanaimi H et al (2014) Late EdiacaranCambrian structures and their reactivation during the Variscan and Alpine cycles in the Anti-Atlas (Morocco). J Afr Earth Sci 98:94-112. doi:10.1016/j.jafrearsci.2014.04.025

Thomas RJ, Chevallier LP, Gresse PG et al (2002) Precambrian evolution of the Sirwa Window, Anti-Atlas Orogen, Morocco. Precambrian Res 118:1-57. doi:10.1016/S0301-9268(02)00075-X

Timmerman MJ (2008) Palaeozoic magmatism. In: Mccann T (ed) The Geology of Central Europe. Geological Society, London, pp 665-748

Touil A, Vegas R, Hafid A et al (2008) Petrography, mineralogy and geochemistry of the Ighrem diabase dyke (Anti-Atlas, Southern Morocco). Rev Soc Geol Espana 21:25-33

Tucholke BE, Sawyer DS, Sibuet J-C (2007) Breakup of the Newfoundland-Iberia rift. Geol Soc Lond Spec Publ 282:9-46. doi: $10.1144 / \mathrm{SP} 282.2$

Verati C, Rapaille C, Féraud G et al (2007) 40Ar/39Ar ages and duration of the Central Atlantic Magmatic Province volcanism in Morocco and Portugal and its relation to the Triassic-Jurassic boundary. Palaeogeogr Palaeoclimatol Palaeoecol 244:308-325

Vitorello I, Pollack HN (1980) On the variation of continental heat flow with age and the thermal evolution of continents. J Geophys Res Solid Earth 85:983-995. doi:10.1029/ JB085iB02p00983

Walsh GJ, Aleinikoff JN, Benziane F et al (2002) U-Pb zircon geochronology of the Paleoproterozoic Tagragra de Tata inlier and its Neoproterozoic cover, western Anti-Atlas, Morocco. Precambrian Res 117:1-20. doi:10.1016/S0301-9268(02)00044-X

Youbi N, Martins LT, Munhá JM et al (2003) The late Triassic-early Jurassic volcanism of Morocco and Portugal in the Framework of the Central Atlantic Magmatic Province: an overview. In: Hames W, Mchone JG, Renne P, Ruppel C (eds) The Central Atlantic Magmatic Province: Insights from Fragments of Pangea. American Geophysical Union, pp 179-207

Zouhri S, Kachikach A, Saddiqi O et al (2008) The cretaceous-tertiary plateaus. In: Michard A, Saddiqi O, Chalouan A, de Lamotte DF (eds) Continental evolution: the geology of Morocco. Springer, Berlin 